\title{
The impact of overshooting deep convection on local transport and mixing in the tropical upper troposphere/lower stratosphere (UTLS)
}

\author{
W. Frey ${ }^{1, *}$, R. Schofield ${ }^{1}$, P. Hoor ${ }^{2}$, D. Kunkel ${ }^{2}$, F. Ravegnani ${ }^{3}$, A. Ulanovsky ${ }^{4}$, S. Viciani ${ }^{5}$, F. D'Amato ${ }^{5}$, and \\ T. P. Lane ${ }^{1}$ \\ ${ }^{1}$ School of Earth Sciences and ARC Centre of Excellence for Climate System Science, University of Melbourne, \\ Melbourne, Australia \\ ${ }^{2}$ Institute for Atmospheric Physics, Johannes Gutenberg University, Mainz, Germany \\ ${ }^{3}$ Institute of Atmospheric Sciences and Climate, ISAC-CNR, Bologna, Italy \\ ${ }^{4}$ Central Aerological Observatory, Dolgoprudny, Moscow Region, Russia \\ ${ }^{5}$ CNR-INO National Institute of Optics, Florence, Italy \\ *now at: School of Earth, Atmospheric and Environmental Sciences, University of Manchester, UK
}

Correspondence to: W. Frey (wiebke.frey@ manchester.ac.uk)

Received: 21 November 2014 - Published in Atmos. Chem. Phys. Discuss.: 14 January 2015

Revised: 24 March 2015 - Accepted: 16 May 2015 - Published: 12 June 2015

\begin{abstract}
In this study we examine the simulated downward transport and mixing of stratospheric air into the upper tropical troposphere as observed on a research flight during the SCOUT-O3 campaign in connection with a deep convective system. We use the Advanced Research Weather and Research Forecasting (WRF-ARW) model with a horizontal resolution of $333 \mathrm{~m}$ to examine this downward transport. The simulation reproduces the deep convective system, its timing and overshooting altitudes reasonably well compared to radar and aircraft observations. Passive tracers initialised at pre-storm times indicate the downward transport of air from the stratosphere to the upper troposphere as well as upward transport from the boundary layer into the cloud anvils and overshooting tops. For example, a passive ozone tracer (i.e. a tracer not undergoing chemical processing) shows an enhancement in the upper troposphere of up to about $30 \mathrm{ppbv}$ locally in the cloud, while the in situ measurements show an increase of $50 \mathrm{ppbv}$. However, the passive carbon monoxide tracer exhibits an increase, while the observations show a decrease of about $10 \mathrm{ppbv}$, indicative of an erroneous model representation of the transport processes in the tropical tropopause layer. Furthermore, it could point to insufficient entrainment and detrainment in the model. The simulation shows a general moistening of air in the lower stratosphere, but it also exhibits local dehydration features. Here we use the model to explain the processes causing the transport and also expose areas of inconsistencies between the model and observations.
\end{abstract}

\section{Introduction}

The air in the tropical upper troposphere is subject to mean upward transport: above the level of zero radiative heating, the Brewer-Dobson circulation leads to slow upwelling, which can however be penetrated by rapid overshooting convection (Corti et al., 2006; Pommereau, 2010; Randel and Jensen, 2013). In both scenarios air predominantly enters the stratosphere, while stratosphere-to-troposphere exchange preferably occurs around the subtropical jet and in the midlatitudes (Holton et al., 1995; Stohl et al., 2003; Tang et al., 2011). In tropical deep convection, strong upper-level updrafts are not uncommon, and there are also strong upperlevel downdrafts associated with these (Heymsfield et al., 2010). These downdrafts in tropical overshooting deep convection may irreversibly transport stratospheric air across the tropopause into the upper troposphere, but the extent to which they impact upper tropospheric chemistry and the net flux across the tropopause is currently unclear.

The tropical tropopause layer (TTL), defined by Fueglistaler et al. (2009) as the layer above the level of main convective outflow $(14 \mathrm{~km} / 355 \mathrm{~K})$ and up to $18.5 \mathrm{~km} / 425 \mathrm{~K}$, is the interface between the free troposphere and the stratospheric overworld. Ozone and water vapour in the TTL have important roles, e.g. for the radiation budget and thus surface temperatures (Solomon et al., 2010), both being major greenhouse gases (Huntrieser et al., 2007). For example, a change in ozone in the TTL of $5 \%$ causes 
a radiative heating response of $0.5 \mathrm{~K} \mathrm{dec}^{-1}$ (Forster et al., 2007). Deep convection, which effectively redistributes trace gases throughout the atmosphere, plays an important role by changing the trace gas composition, including water vapour, in the TTL. Trace gases can be transported from the boundary layer to $15 \mathrm{~km}$ altitude within $30 \mathrm{~min}$ (Thompson et al., 1997), which is fast enough to transport very short lived substances (VSLS) from the boundary layer into the TTL and possibly into the stratosphere. Halogenated VSLS, containing bromine, chlorine, and iodine, play an important role in ozone destruction (Law and Sturges, 2007; Aschmann et al., 2011; Hossaini et al., 2012). Furthermore, anvil clouds originating from deep convection provide surfaces for heterogeneous reactions. For example, von Hobe et al. (2011) show evidence for heterogeneous chlorine activation on TTL cirrus. Thus, transport and mixing of air in the TTL can play an important role in altering chemical species. On the other hand, convective downdrafts can transport free tropospheric air into the boundary layer $(\mathrm{Hu}$ et al., 2010). While the transport in convective updrafts is well studied (e.g. Folkins et al., 2002; Barth et al., 2007; Pommereau, 2010; Romps and Kuang, 2010), especially in the mid-latitudes (e.g. Wang, 2003; Hegglin et al., 2004; Mullendore et al., 2005; Homeyer et al., 2014), only few studies look at the downward transport of tracers triggered by convection (Lu et al., 2000; Hu et al., 2010; Barthe et al., 2011). However, these upper-level downdrafts, which are either direct convective downdrafts or related to gravity waves, may also transport dry and ozone-rich stratospheric air across the tropopause (Lu et al., 2000). Downward transport of stratospheric air in relation to convection has been reported in the mid-latitudes (e.g. Shapiro, 1980; Lamarque et al., 1996; Poulida et al., 1996; Stenchikov et al., 1996; Chagnon and Gray, 2010; Pan et al., 2014). This implies that mixing of boundary layer and stratospheric air could happen in the upper tropical troposphere in connection with deep convection. Pommereau (2010) points out that convective transport could play a more important role in troposphere-to-stratosphere transport than slow radiative ascent; however, the implications of such transport and mixing for the TTL chemistry are unknown.

Deep convective clouds may even overshoot into the stratosphere, injecting trace gases, water vapour, and even ice crystals directly (Corti et al., 2008; de Reus et al., 2009). There has been an ongoing debate about whether these injections lead to dehydration or hydration of the stratospheric air. It was argued that water vapour would condense onto the overshooted ice crystals which then sediment back to the troposphere (Danielsen, 1982) and thus dehydrate the air. However, in situ observations as well as modelling results during the last decade suggest a net hydrating effect (e.g. Chaboureau et al., 2007; Corti et al., 2008; Chemel et al., 2009; de Reus et al., 2009; Pommereau, 2010), mainly by direct injection of water vapour and ice that sublimates in the stratosphere. However, idealised simulations have shown the importance of prevailing TTL background conditions (Jensen et al., 2007; Hassim and Lane, 2010): by driving the humidity in the TTL towards ice saturation, overshooting convection may dehydrate or hydrate, depending on whether the TTL was supersaturated or subsaturated before. Hassim and Lane (2010) found net hydration in the stratosphere, which was subsaturated, regardless of the TTL humidity. At present it is unclear what the relative impacts of these localised storms are on the global scale, though observational campaigns during the early years of this millennium demonstrated a high frequency of overshooting events (Pommereau, 2010), which contrast with the generally assumed scarcity of these events. A high-resolution climatology of the extent and number of overshooting convection events would be needed to fully quantify their impact.

During the Australian pre-monsoon season (NovemberDecember), a very intense deep convective storm system develops almost daily over the Tiwi Islands near Darwin (so-called "Hector"; Keenan et al., 1994; Carbone et al., 2000; Crook, 2001). In general, Hector develops as a consequence of converging sea breezes and interacting cold pools (Carbone et al., 2000). Due to the high probability of Hector developing, several observational experiments have been carried out in Darwin, Northern Territory (Australia). One of these campaigns was the SCOUT-O3 experiment (Stratospheric-Climate Links with Emphasis on the Upper Troposphere and Lower Stratosphere; Brunner et al., 2009) in November-December 2005. The aim of this campaign was to study the transport of trace gases and water vapour and the role of deep convection therein.

This paper presents a combination of in situ measurements and modelling results of a Hector storm system during the SCOUT-O3 campaign. The observations and simulation show the importance of downdrafts from the stratosphere for the composition of trace gases. Additionally, the impact of the overshooting convection on the water vapour in the TTL and lower stratosphere is studied.

\section{Measurements and case description}

This case study focusses on measurements and simulations of a Hector thunderstorm on 30 November 2005. On this day an intense Hector developed above the Tiwi Islands, which is described in detail by Chemel et al. (2009). Chemel et al. use simulations performed with the Weather Research and Forecasting (WRF) model and the UK Met Office Unified Model (UM). In situ cloud microphysical measurements of this storm are reported by Frey et al. (2014). These measurements were obtained aboard the high-altitude aircraft Geophysica as part of the SCOUT-O3 campaign (Brunner et al., 2009). Convection was initiated around 03:30 UTC (13:00 LT; LT $=$ UTC + 9:30; Brunner et al., 2009) and the research flight took off at 03:44 UTC (Frey et al., 2014). During this research flight, measurements in overshooting cloud 


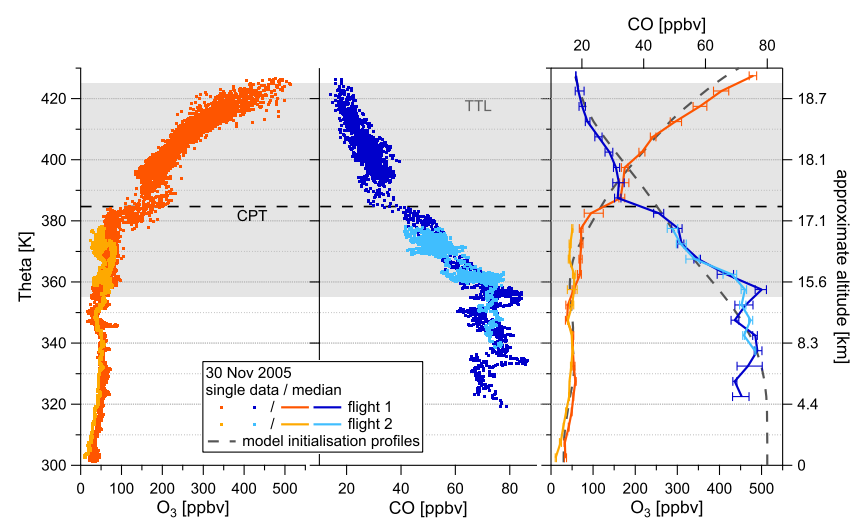

Figure 1. Observed ozone and carbon monoxide mixing ratio profiles (left and middle panel) during the double flight on 30 November 2005. On the right, the median observed profiles with the 33 and 67 percentiles (error bars) are shown together with the model initialisation profiles (see Sect. 5). The shading indicates the TTL as defined by Fueglistaler et al. (2009) and the dashed line indicates the cold point tropopause (CPT).

turrets were performed, which penetrated into the stratosphere up to potential temperatures of $417 \mathrm{~K}$; see Corti et al. (2008) and de Reus et al. (2009) for details. These studies show that the observed cloud particles were a result of convective overshooting and did not form in situ. The overshoots were encountered by the Geophysica between about 05:40 and 07:00 UTC at altitudes between 18.0 and $18.7 \mathrm{~km}$ (de Reus et al., 2009). The Darwin C-band polarimetric radar (CPOL; Hassim et al., 2014) confirmed this and detected overshooting cloud turrets with maximum echo top heights of $19 \mathrm{~km}$ over the Tiwi Islands between 04:00 and 07:00 UTC (Vickal Kumar, personal communication). Additionally, trace gas measurements were obtained for ozone and carbon monoxide aboard the Geophysica by the Fast OZone ANalyzer (FOZAN; Yushkov et al., 1999; Ulanovsky et al., 2001) and the Cryogenically Operated Laser Diode (COLD; Viciani et al., 2008) instruments. FOZAN is a chemiluminescence sensor with an accuracy of $10 \%$ and a precision of $0.01 \mathrm{ppm}$ that measures ozone mixing ratios at $1 \mathrm{~Hz}$ sampling frequency. COLD has an accuracy of 6-9\% at the lower detection limit of a few $\mathrm{nmol} \mathrm{mol}^{-1}$, and a precision of $1 \%$. Its sampling frequency is $0.2 \mathrm{~Hz}$. At given aircraft speeds the sampling frequencies of the instruments translate to horizontal distances of 150-200 $\mathrm{m}$ and $750-1000 \mathrm{~m}$, respectively.

The Geophysica performed two flights on 30 November, the first flight mainly around and above the developing and mature Hector, the second flight in Hector cloud remnants. FOZAN and COLD were operational during both flights and the measured profiles are shown in Fig. 1. Both species show a distinct feature around the $390 \mathrm{~K}$ level: clearly elevated ozone mixing ratios and decreased $\mathrm{CO}$ mixing ratios relative to those expected in typically shaped profiles are seen. The deviations of the observed median profile from the ex- pected typically shaped profile are about $+50 \mathrm{ppbv}$ for ozone and $-10 \mathrm{ppbv}$ for $\mathrm{CO}$. While photochemical production of ozone can occur in deep convection due to lightning, this would not affect the CO mixing ratios. While COLD made no observations in the lower troposphere, $\mathrm{CO}$ sinks there can be excluded, as measurements performed aboard the Egrett aircraft during the same campaign time show (Allen et al., 2008). They found CO mixing ratios of approximately 80$100 \mathrm{ppbv}$ at the altitudes up to $4 \mathrm{~km}$. On the other hand, stratospheric air is $\mathrm{CO}$ poor and ozone rich. The reduction in ozone mixing ratios between 360 and $380 \mathrm{~K}$ during the second flight indicates convective influence on the profile (by upward transport of ozone-poorer air from the boundary layer, e.g. Folkins et al., 2002). Further indication of convective influence is given by the non-volatile aerosol measurements shown by de Reus et al. (2009, their Fig. 8), where elevated non-volatile aerosol concentrations can be found above $390 \mathrm{~K}$. Furthermore, a trajectory analysis was conducted to exclude the influence of a large-scale stratospheric intrusion. The kinematic trajectories were calculated with LAGRANTO (Wernli and Davies, 1997) based on ECMWF operational analysis fields with a horizontal grid spacing of $0.125^{\circ}$ and 60 vertical levels and were initialised on 30 November 2005 at 06:00 UTC, at different altitudes, i.e., $75,80,85,90 \mathrm{hPa}$, above the Tiwi Islands. From this analysis it was concluded that the measured tracers were not significantly influenced by a large-scale stratospheric filament (not shown), but were rather modified by local processes. Synthesising this information, the observed ozone and $\mathrm{CO}$ profiles therefore imply downward transport of stratospheric air.

While several studies have examined the effect of overshooting on the upward transport of air masses into the stratosphere, particularly looking at humidity and also cloud particles, the role of downward transport has seldom been in the focus or reproduced by models. However, in-mixing of dry and ozone-rich stratospheric air into the TTL will have important implications for the radiative forcing, chemistry, cloud formation, and humidity here.

\section{Model and its configuration}

The Advanced Research WRF (WRF-ARW) Version 3.4.1 was used to simulate the Hector storm system that developed on 30 November 2005. The model was run using five one-way nested domains. The innermost domain (domain 5) was centred above the Tiwi Islands, north of Darwin, Australia. The locations of the domains as well as their horizontal grid spacing $(\Delta x)$ are given in Fig. 2. The computations were made on 129 vertical levels up to a pressure level of $10 \mathrm{hPa}$, with around $100 \mathrm{~m}$ vertical spacing in the TTL. For the outermost domain, a time step of $90 \mathrm{~s}$ is used; the nested domains have a nest-to-parent time step ratio of $3: 1$. A $5 \mathrm{~km}$ deep implicit gravity-wave damping layer is established and vertical velocity damping is also used. Meteorological initial 


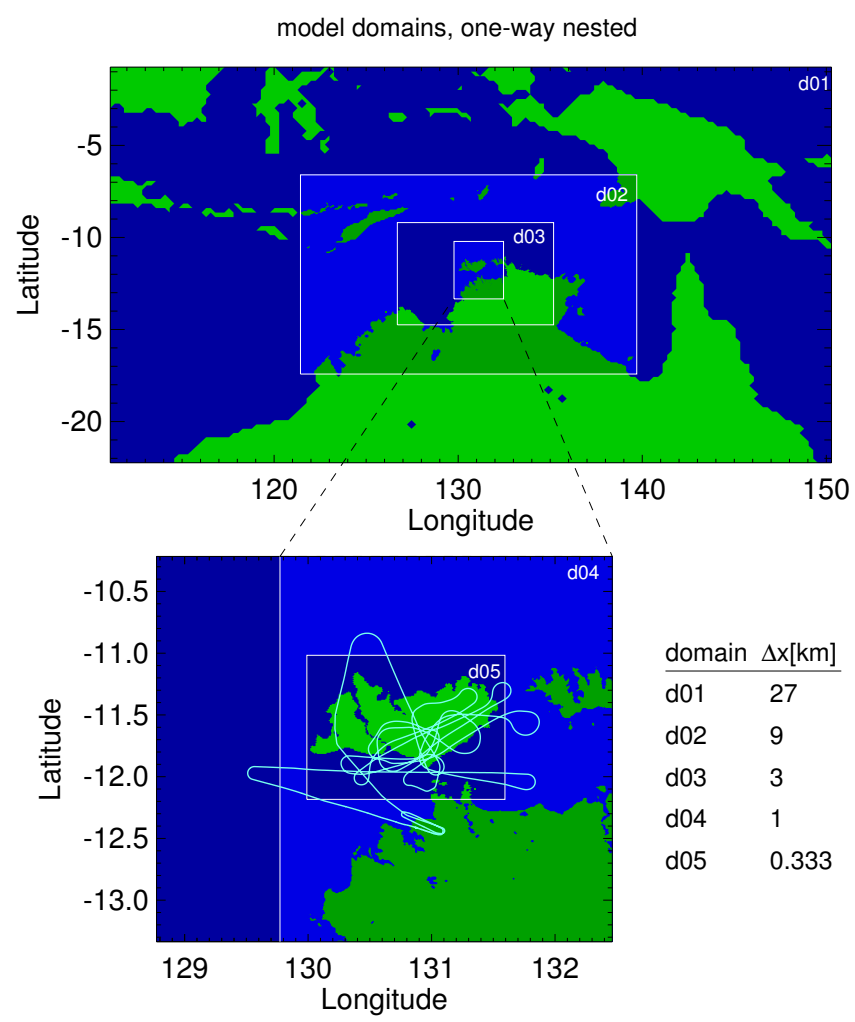

Figure 2. Location of model domains and their horizontal grid spacing. The Geophysica flight path is superimposed in light blue.

and boundary conditions were derived from the ERA Interim reanalysis (Dee et al., 2011) model level data with 60 vertical levels and a horizontal spacing of $0.75^{\circ}$. The model was initialised on 29 November at 12:00 UTC to allow for model spin-up. An earlier start $(6,12,24 \mathrm{~h})$ resulted in a weaker Hector or Hector not evolving at all.

The Tiwi Islands are generally flat; however, there is a mountain ridge that might affect Hector development. Therefore, 3 arc-seconds (about $90 \mathrm{~m}$ ) Shuttle Radar Topography Mission (SRTM; Farr et al., 2007) topography replaces the standard WRF topography on domains 4 and 5 in this study and 30 arc-seconds SRTM data were used on domain 3 (to give a smooth transition to the lower-resolution WRF topography domains and to avoid boundary problems). For the land use categories we used MODerate resolution Imaging Spectroradiometer (MODIS; Friedl et al., 2002) data at $1 \mathrm{~km}$ resolution and the Noah land surface model (Chen and Dudhia, 2001).

For the surface and boundary layer, the quasi-normal scale elimination (QNSE) scheme is used (Sukoriansky et al., 2005). The QNSE scheme is classified as a turbulent kinetic energy (TKE) closure scheme. The daytime part uses the eddy diffusivity mass-flux (EDMF; Pergaud et al., 2009) method with shallow convection, with the mixing height diagnosed on the basis of TKE. While vertical diffusion is performed by the PBL scheme, we use a simple hori- zontal diffusion option along the model levels. The $\mathrm{K}$ coefficient for horizontal diffusion is diagnosed from horizontal deformation and stability following a Smagorinsky approach. A positive definite sixth-order horizontal hyperdiffusion is used to act as a selective shortwave numerical noise filter. For the computation of long- and short-wave radiation, we used the Rapid Radiative Transfer Model for GCM schemes (RRTMG; Iacono et al., 2008), an improved version of the RRTM. The RRTMG schemes work with the Monte Carlo Independent Column Approximation (MCICA) method of random cloud overlap. It is used operationally in the ECMWF weather forecast system. Cumulus parameterisation is applied for domains 1 and 2, namely, the BettsMiller-Janjic operational eta scheme (Janjic, 1994). Convection is treated explicitly on the other three domains. For the cloud microphysical calculations, the NSSL two-moment microphysics (Mansell et al., 2010) is implemented. The NSSL scheme calculates cloud water, rain, ice, snow, graupel, and hail and the corresponding hydrometeor number concentrations.

\section{Hector development}

The background conditions of several meteorological parameters as simulated in the innermost domain are shown in Fig. 3. The cold point tropopause can be found at $16.9 \mathrm{~km}$ and the hygropause just $100 \mathrm{~m}$ above. The cold point tropopause as observed by the Geophysica was located at $17.3 \mathrm{~km}$ (de Reus et al., 2009); however, it has to be cautioned that the measurements were taken during the flight when Hector had already developed, and are thus not directly comparable to the domain average presented here. The height of the simulated cold point tropopause changes to $16.8 \mathrm{~km} / 16.8 \mathrm{~km} / 17.1 \mathrm{~km}$ at 06:00 UTC/09:00 UTC/12:00 UTC. Between $13.9 \mathrm{~km}$ and $16.3 \mathrm{~km}$, the relative humidity with respect to ice $\left(\mathrm{RH}_{\mathrm{i}}\right)$ reaches above $100 \%$, with a maximum of $105 \%$ at $15.4 \mathrm{~km}$.

The evolution of simulated $10 \mathrm{~m}$ winds, radar reflectivity $^{1}$ at $10 \mathrm{~km}$ altitude, column maximum radar reflectivity, and outgoing longwave radiation (OLR) is shown in Fig. 4. One deep convective cell develops over the eastern part of Bathurst Island (the smaller island to the west) and a stronger cell at the eastern part of the mountain ridge on Melville Island in the island's south-east. Subsequently the latter cell travels along the ridge towards the west. The radial outflow from cold pools evolves into an offshore flow to the southeast of Melville Island between 05:30 and 06:00 UTC. The locations of the modelled cloud signals compare reasonably well to observations as shown in Brunner et al. (2009, cf. their Fig. 13). Satellite images (not shown) illustrate that in its mature stage Hector starts travelling towards the north-

\footnotetext{
${ }^{1}$ The radar reflectivity is calculated by the NSSL microphysics scheme following Ferrier (1994), assuming pure Rayleigh scattering.
} 


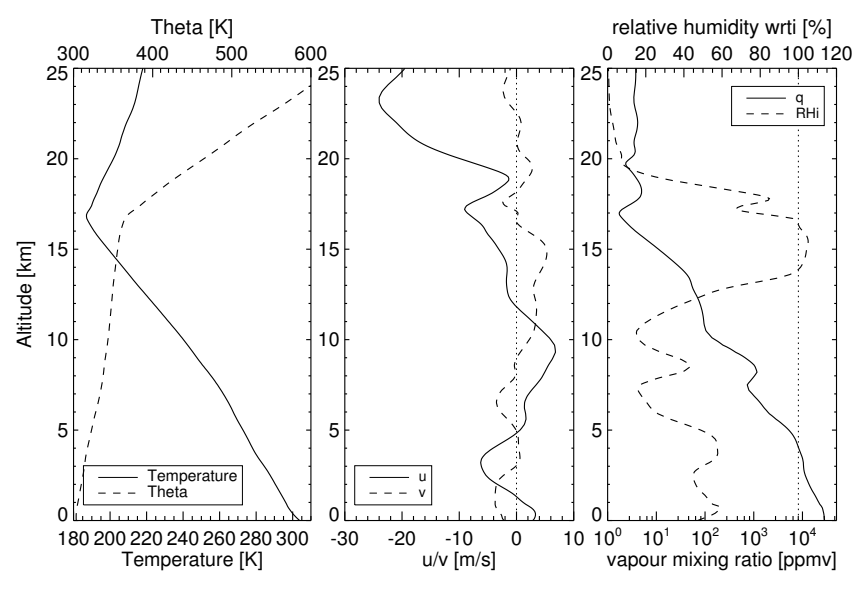

Figure 3. Profile of meteorological parameters prior to Hector development (04:30 UTC). Profiles are averaged over domain 5 and show temperature and potential temperature in the left panel, the $u$ and $v$ wind components in the middle panel, and relative humidity with respect to ice and water vapour mixing ratio in the right panel.

west between 06:33 and 07:33 UTC, whereas in the modelled OLR fields this shift happens about half an hour later. At this later stage the anvil identified by OLR covers much of Melville Island.

The vertical evolution of Hector is shown in Fig. 5. The zonal cross section is chosen in a way that it intersects the convective core at around the highest updraft and downdraft speeds. The dashed line indicates the $0.01 \mathrm{~g} \mathrm{~kg}^{-1}$ ice mixing ratio, often used to represent the cloud boundary. The cloud layer around $15 \mathrm{~km}$ (which developed over night) would under that definition not count as cloud. This is also the altitude of slight supersaturation (cf. Fig. 3) which presumably leads to the formation of thin ice clouds. The first convective cell develops at around $130.45^{\circ} \mathrm{E}$ at 04:30 UTC (cf. the Bathurst cell in Fig. 4) and reaches its maximum altitude of about $13 \mathrm{~km}$ at 04:50 UTC. However, the cross sections here do not intersect the middle of this cell, since it ceases, and a second, stronger cell starts developing at 04:40 UTC, around $131.1^{\circ} \mathrm{E}$. The cloud tops shown in Fig. 5 exhibit ice water content (IWC) and number concentrations (not shown) similar to those reported by the measurements in de Reus et al. (2009). The timing of the simulated overshoots is similar to that of the Geophysica measurements; however, the CPOL radar reported frequent overshoots from 04:30 UTC (inferred here from cloud tops higher than the average cloud top). The aircraft was simply not at those altitudes at the time of the first overshoots. As with the comparison of OLR fields with the satellite images, the modelled Hector overshoots indicate a lag in timing of approximately half an hour to an hour.

The development of the modelled Hector was sensitive to the chosen boundary and surface layer schemes and model initialisation time. Particularly, the strength of Hector and the maximum overshooting altitude were affected. The sensitivity to surface and boundary layer schemes was also shown by
Hoyle et al. (2011), who compared the tropical transport processes of 14 different (lower-resolution) models. In our case, the QNSE surface and boundary layer schemes gave the best results in reproducing Hectors' cloud top altitude, compared to the CPOL radar and aircraft measurements. While replacing the WRF topography on domains 3, 4, and 5 with SRTM topography improved timing by about $20 \mathrm{~min}$ (on domain 4), the higher resolution of domain 5 again improved the timing of Hector onset by a further $30 \mathrm{~min}$ relative to domain 4. There is also a slight sensitivity towards the cloud microphysical scheme used. In addition to the NSSL microphysics, the WDM6, Thompson, and Morrison two-moment schemes (Lim and Hong, 2010; Thompson et al., 2008; Morrison et al., 2009) were tested. While Thompson, Morrison, and NSSL all simulated Hectors with clouds reaching high into the TTL, convection in the WDM6 scheme just reached up to $10 \mathrm{~km}$. From the remaining three, the Thompson scheme produced the smallest Hector in horizontal and vertical extension. Morrison and NSSL simulated higher vertical wind speeds (about $8-10 \mathrm{~ms}^{-1}$ higher) and higher reaching turrets, also producing overshooting into the stratosphere, as observed. The NSSL scheme achieved slightly larger horizontal and vertical extents than the Morrison scheme. While the timing is similar for the Thompson and Morrison schemes, the NSSL scheme showed a better timing by about half an hour. Thus, overall, the NSSL scheme performed best, and was chosen for the rest of the study.

\section{Convective transport and mixing of passive tracers}

\subsection{Passive layer tracers}

To gain a closer look at the redistribution of air masses in the TTL due to deep convection, passive tracers have been initialised at 04:30 UTC. This time was chosen since convection was shallow and did not reach above $5 \mathrm{~km}$ and, thus, it is a time prior to the development of Hector (see Fig. 5). More importantly, the TTL was still in its pre-convection state. Two initial sets of passive tracers were introduced on different altitude and potential temperature layers as indicated in Table 1 . The values of the passive tracers in the respective layers were set to 1 , while the layers above and below remained at 0 .

Figure 6 shows vertical cross sections of BLA, A1, A2, A3, and A4 distributions at 06:00 and 12:00 UTC. The distribution of the tracers during the mature stage of Hector (06:00 UTC) not only shows the upward transport of air masses from the lower levels (BLA, A1, and A2), but also significant downward transport from the upper layers (A2, A3, and A4). The boundary layer tracer as well as the free tropospheric tracer (BLA and A1) are transported high up into the TTL; the boundary layer tracer is transported with greater efficiency than the free tropospheric tracer. Both tracers are still visible after convection ceased at 12:00 UTC, 


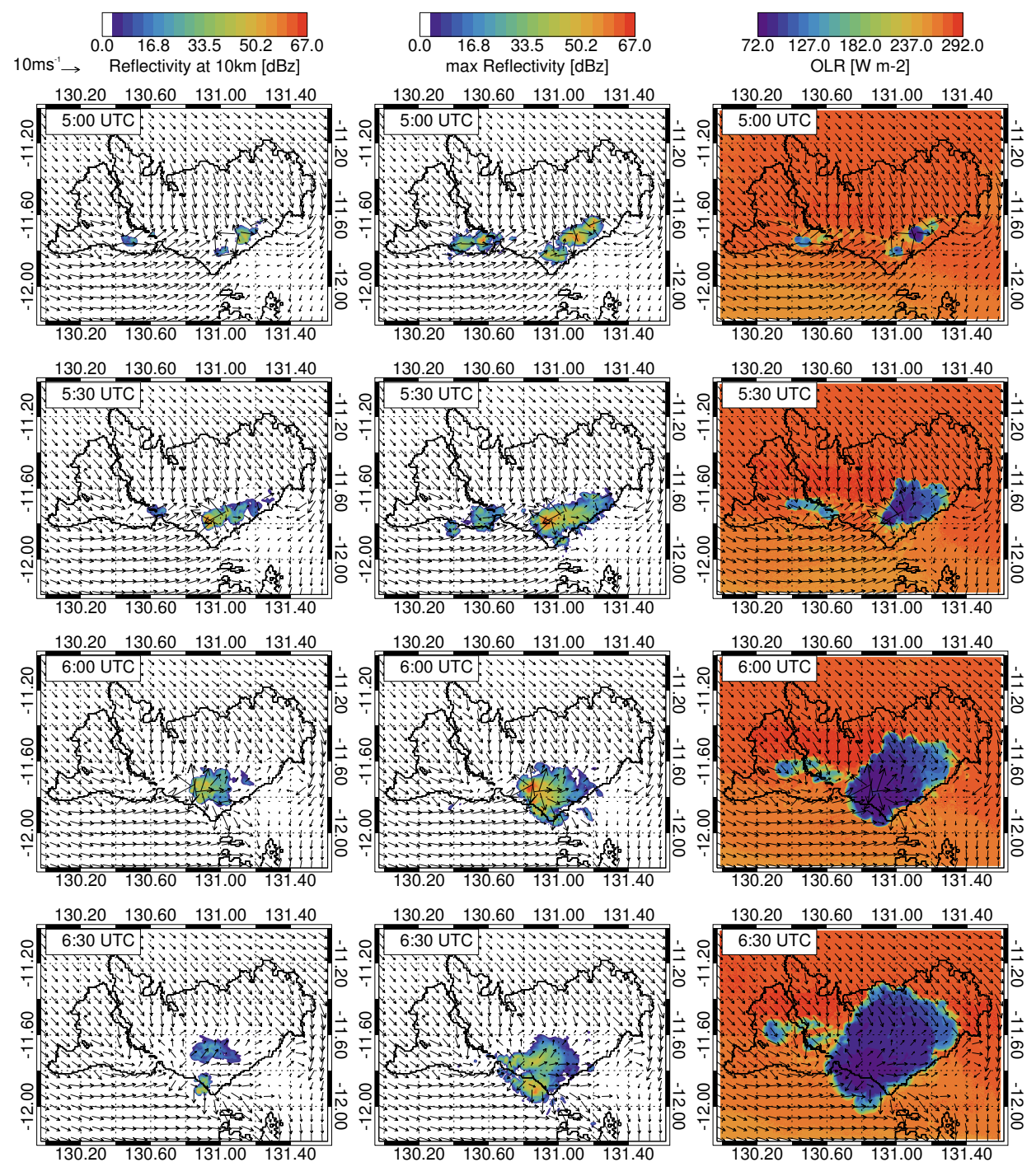

Figure 4. Evolution of $10 \mathrm{~m}$ surface winds (arrows), radar reflectivity at $10 \mathrm{~km}$ altitude (left panels), column maximum reflectivity (middle panels), and OLR (right panels) as simulated in domain 5.

Table 1. Specification of passive tracer layers. The tracers carry an amount of 1 in these layers and are 0 outside at the time of tracer initialisation at 04:30 UTC.

\begin{tabular}{crlr}
\hline \multicolumn{2}{c}{ Altitude tracer } & \multicolumn{2}{c}{ Potential temperature tracer } \\
\hline BLA & $<2 \mathrm{~km}$ & BLT & $<315 \mathrm{~K}$ \\
A1 & $2-10 \mathrm{~km}$ & T1 & $315-350 \mathrm{~K}$ \\
A2 & $14-16 \mathrm{~km}$ & T2 & $350-370 \mathrm{~K}$ \\
A3 & $16-18 \mathrm{~km}$ & T3 & $370-390 \mathrm{~K}$ \\
A4 & $18-20 \mathrm{~km}$ & T4 & $390-410 \mathrm{~K}$ \\
& & T5 & $410-430 \mathrm{~K}$ \\
\hline
\end{tabular}

suggesting irreversible transport. Small amounts of BLA, A1, and A2 even reach up to about $21 \mathrm{~km}$ at 09:00 UTC and fall back to $20 \mathrm{~km}$ at 12:00 UTC (on scales smaller than plot- ted here). Only A4 reaches somewhat higher into the stratosphere, which is not surprising since its initialisation altitude is already situated in the lower stratosphere. Some signs of upward transport are also visible in the other tracers, but considerable amounts of air have been mixed downward at the same time. The TTL tracers A2, A3, and A4 all show downward transport reaching several kilometres below their initialisation layers. The transport of the tracers is also crossisentropic, as can be seen in Fig. $7^{2}$. Here, the domain averaged profiles of the potential temperature layer passive trac-

\footnotetext{
${ }^{2}$ Linear interpolation has been applied in the vertical to regrid data onto a regular potential temperature ordinate (Figs. 7-11, 13, 14). Care should be taken interpreting the figures when isentropes are near vertical. However, different interpolation methods lead to almost identical results.
} 

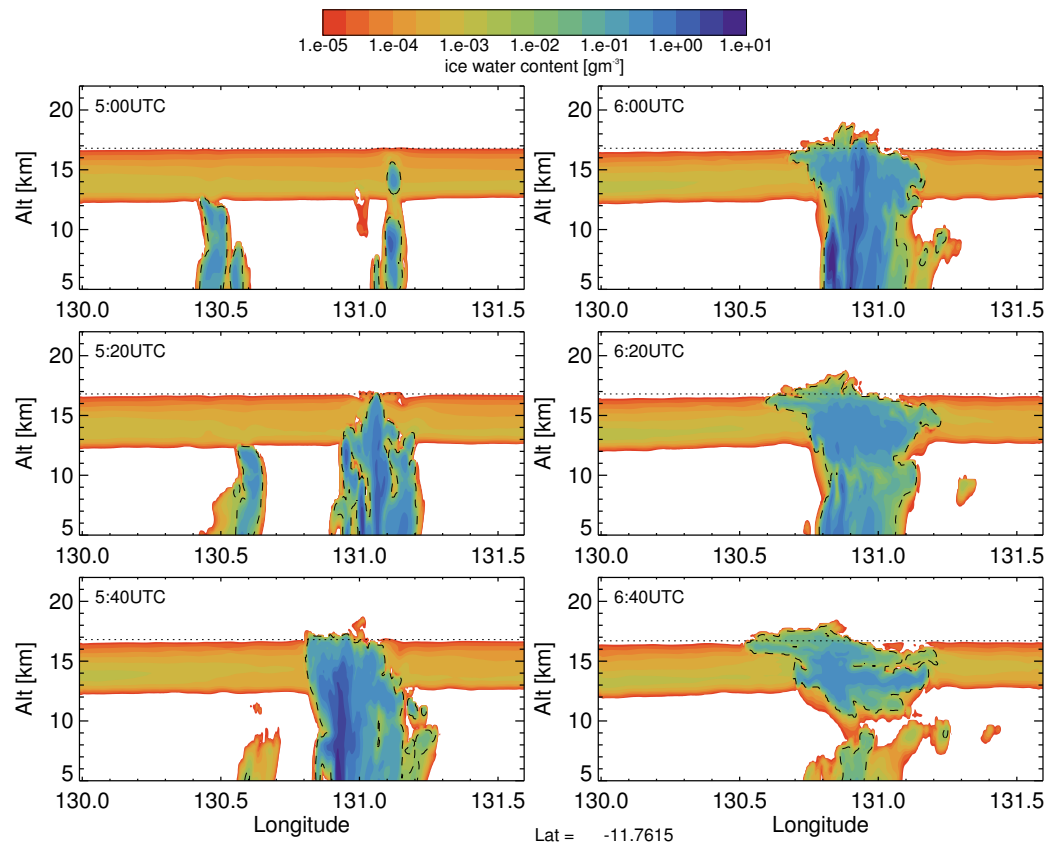

Figure 5. IWC cross sections between 05:00 and 06:40 UTC. The dashed line represents the $0.01 \mathrm{~g} \mathrm{~kg}^{-1}$ ice mixing ratio, representing the cloud boundary, and the dotted line indicates the simulated cold point tropopause.

ers are shown at 06:00, 09:00, and 12:00 UTC, plus the incloud averages of the tracers at 06:00 UTC.

As one might expect, the in-cloud averages show much higher values of the tracers than the domain averages (note the different $x$ axis scale for the in-cloud averages). This is because the transport of air masses happens on the convective cloud scale and mostly does not spread out horizontally during the mature Hector. Plus, the domain averages also average over non-convectively influenced regions. It is interesting to note that above roughly $355 \mathrm{~K}$ the boundary layer tracer BLT is more abundant than the free tropospheric tracer T1. The profiles show that there is in-mixing of boundary layer air as well as lower stratospheric air in the TTL. Even hours after Hector (12:00 UTC), signs of the tracers can be found outside their initialisation layers, showing the potential for boundary layer and stratospheric air to mix and undergo chemical processing.

\subsection{Passive ozone and passive $\mathrm{CO}$ tracers}

As discussed in Sect. 2, the trace gas measurements during the SCOUT-O3 flight on 30 November 2005 indicate downward mixing of stratospheric air into the upper troposphere (cf. Fig. 1). To examine this in the model, idealised profiles of ozone and $\mathrm{CO}$ were used to initialise a further set of passive tracers, hereafter $p \mathrm{O}_{3}$ and $p \mathrm{CO}$. We did not use the profile measured by the ozonesonde on this case study day, since this profile was influenced by the active Hector. Instead the ozone profile used here is a smoothed version of the observed ozonesonde profile from 4 December 2005, a non Hector day with a clearer resemblance to background conditions. An idealised $\mathrm{CO}$ profile adapted from the flight profile on 25 November 2005, with high values in the troposphere and low values in the stratosphere, is used as the $p \mathrm{CO}$ initialisation profile. Since these are passive tracers, there is no chemical processing, but only transport and mixing. The initialisation profiles for $p \mathrm{O}_{3}$ and $p \mathrm{CO}$ are shown in Fig. 1 in the right panel.

One of the first simulated overshoots reaching the tropopause region occurred at 05:20 UTC. A longitudinal cross section of the vertical wind field through the convective core is shown in Fig. 8a. The $0.01 \mathrm{~g} \mathrm{~kg}^{-1}$ cloud contour is superimposed as well as isolines of the $\mathrm{pO}_{3}$ tracer. The top of the cloud is located in a downdraft region, indicating that the overshooting updraft is collapsing, while to the west (downstream) there is a small updraft stream. The $p \mathrm{O}_{3}$ isolines show a downward transport of $p \mathrm{O}_{3}$-richer air from above in the downdraft. This is corroborated with the T4 tracer field that is shown in Fig. 8b. Amounts of this tracer reach down into the cloud (to about $350 \mathrm{~K}$ ) whose cloud top is at $390 \mathrm{~K}$, the lower level of the tracer initialisation layer. In Fig. 8c the wind field is overlain with $p \mathrm{CO}$ isolines. Interestingly, these do not provide an indication of downward transport of stratospheric air, but of upward transport of lower tropospheric air. The lower right panel shows the boundary layer tracer BLT (initialised below $315 \mathrm{~K}$ ). It illustrates that boundary layer air can be found throughout the cloud. These tracer perturbations imply that mixing within the cloud is very active.

In a second example, a stronger overshoot during the mature Hector is shown in Fig. 9. Again, downward mixing 

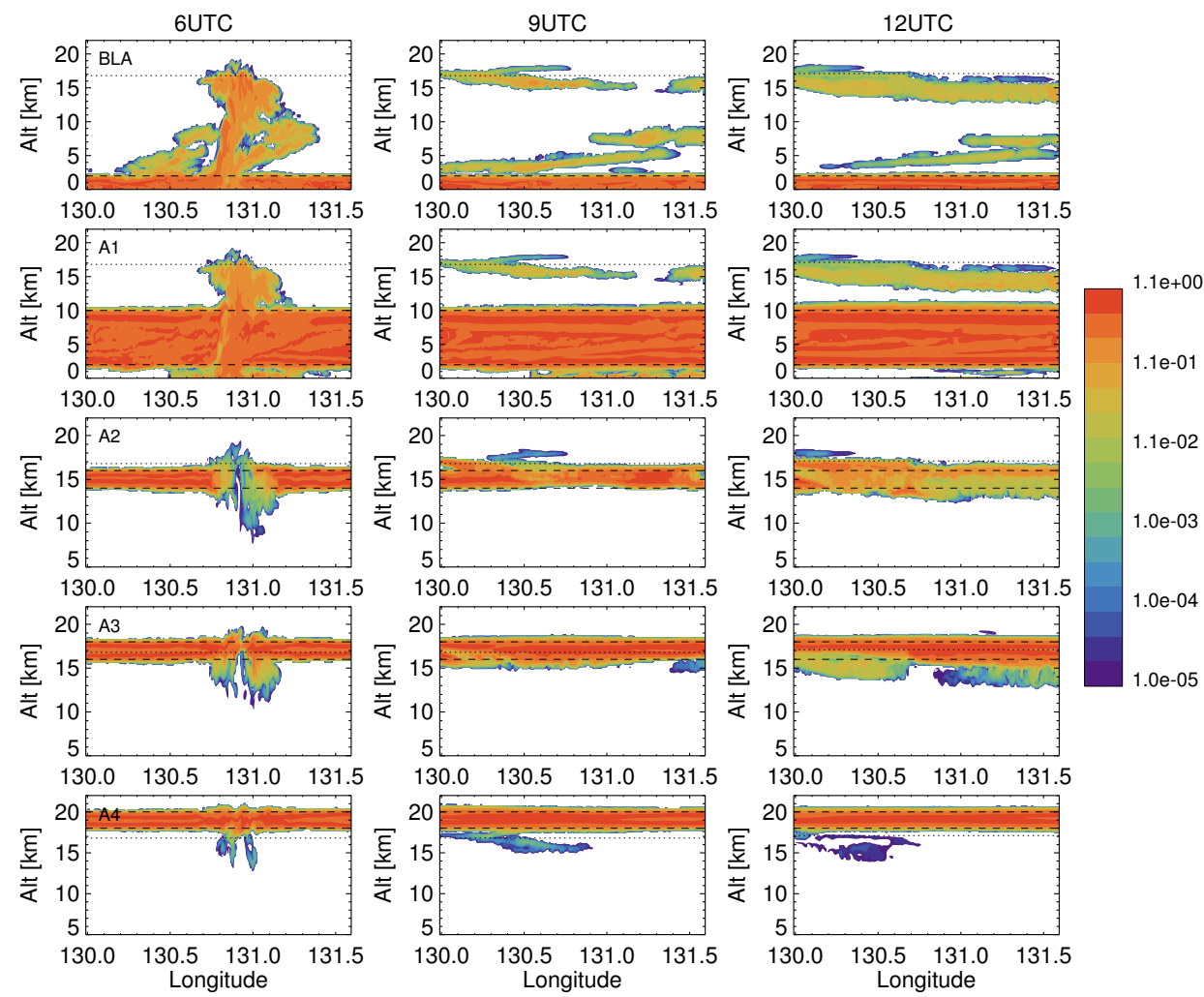

Figure 6. Cross sections of the passive altitude layer tracers at 06:00 UTC (left panels) and 12:00 UTC (right panels). Shown are, from top to bottom, BLA (initialised below $2 \mathrm{~km}$ ), A1, A2, A3, and A4. The initialisation layers of the passive tracers are indicated by the dashed lines. The simulated cold point tropopause is shown by the dotted line. Note the changing $y$ axis scale.

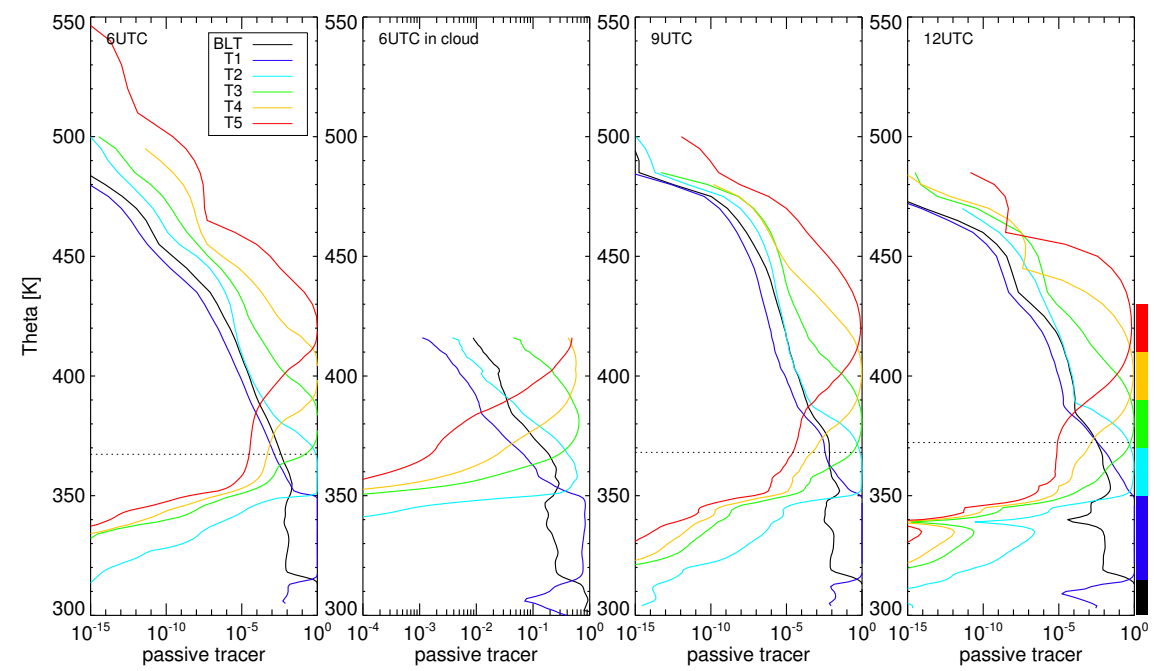

Figure 7. Domain average profiles of passive tracers BLT and T1-T5 at 06:00 UTC (left), 09:00 UTC (second from right), and 12:00 UTC (right), and in-cloud averages at 06:00 UTC (second from left). The coloured blocks on the right indicate the initialisation layer of the respective passive tracer, in which the tracers have a value of 1 ; they are 0 outside the layer.

of $\mathrm{pO}_{3}$-rich air can be seen; e.g. compare the tilt in the $120 \mathrm{ppbv}$ isoline that approaches the altitude of the $90 \mathrm{ppbv}$ background surface. Thus, an enhancement of about $30 \mathrm{ppbv}$ can be found locally. The in situ measurements exhibit an increase of about $50 \mathrm{ppbv}$. The in-cloud increase in $p \mathrm{CO}$ is in disagreement with the in situ measurements that show a decrease of about 10 ppbv. The T4 and BLT tracers are distributed throughout the upper cloud parts, indicating down- 

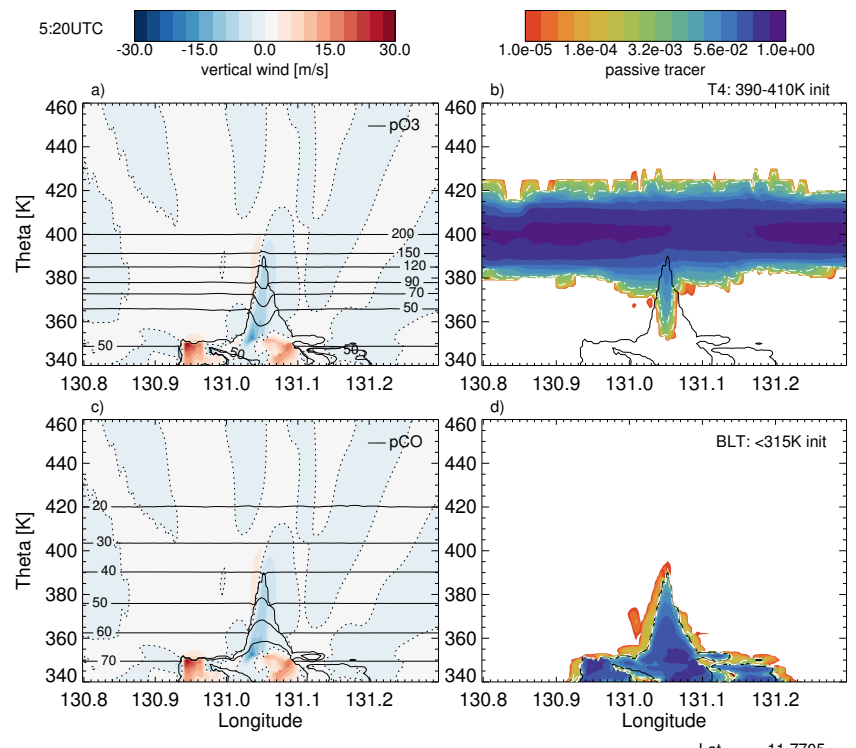

Lat $=-11.7705$

Figure 8. Cross sections through the cloud top at 05:20 UTC. The left panels show the vertical wind (coloured contours) overlain by $\mathrm{pO}_{3}$ isolines (a) and $p \mathrm{CO}$ isolines (c). The right panels show coloured contours of the T4 (b) and BLT (d) tracers. The $0.01 \mathrm{~g} \mathrm{~kg}^{-1}$ cloud contour is displayed on all cross sections. The white dashed/dash-dotted lines indicate the 0.1 and $1 \%$ thresholds of the tracer's original value.

ward as well as upward mixing into the cloud anvil. The fact that $p \mathrm{CO}$ increases in the cloud suggests that there is more boundary layer tracer mixed upwards than stratospheric tracer downwards.

The mixing pattern as well as the cloud are highly variable in space and time. This is illustrated in Fig. 10. Here, $\Delta p \mathrm{O}_{3}$, i.e. the difference of the $p \mathrm{O}_{3}$ tracer from the initialisation profile at 04:30 UTC, is shown. The middle panel corresponds to the 06:00 UTC cross section as in Fig. 9. The left panels show the cross sections shifted by $2 \mathrm{~km}$ to the south, the right panels shifted $2 \mathrm{~km}$ to the north. The upper panels show the cross sections $10 \mathrm{~min}$ prior and the lower panels $10 \mathrm{~min}$ later. In general, there is a $p \mathrm{O}_{3}$ increase in the top part of the cloud, while a decrease is obvious in the anvil between 350 and $360 \mathrm{~K}$. The rise seems to be slightly stronger towards the windward (eastern) side of the cloud. Furthermore, in the $420-440 \mathrm{~K}$ layer we find increased $\mathrm{pO}_{3}$; in some subfigures this increase extends further downward towards the cloud.

Profiles of in-cloud averages of passive tracer deviations from the initialisation profiles have been calculated and are displayed in Fig. 11. The reduction of $\mathrm{pO}_{3}$ due to upward transport from the boundary layer is obvious in the free troposphere $(325-360 \mathrm{~K})$. Between 360 and $400 \mathrm{~K}, p \mathrm{O}_{3}$ increases with respect to the background profile, and thus indicates downward mixing of $p \mathrm{O}_{3}$-rich air. The $p \mathrm{CO}$ tracer, on the other hand, shows an increase in the layer around 340$380 \mathrm{~K}$, peaking at about $360 \mathrm{~K}$, where $\Delta p \mathrm{O}_{3}$ changes from

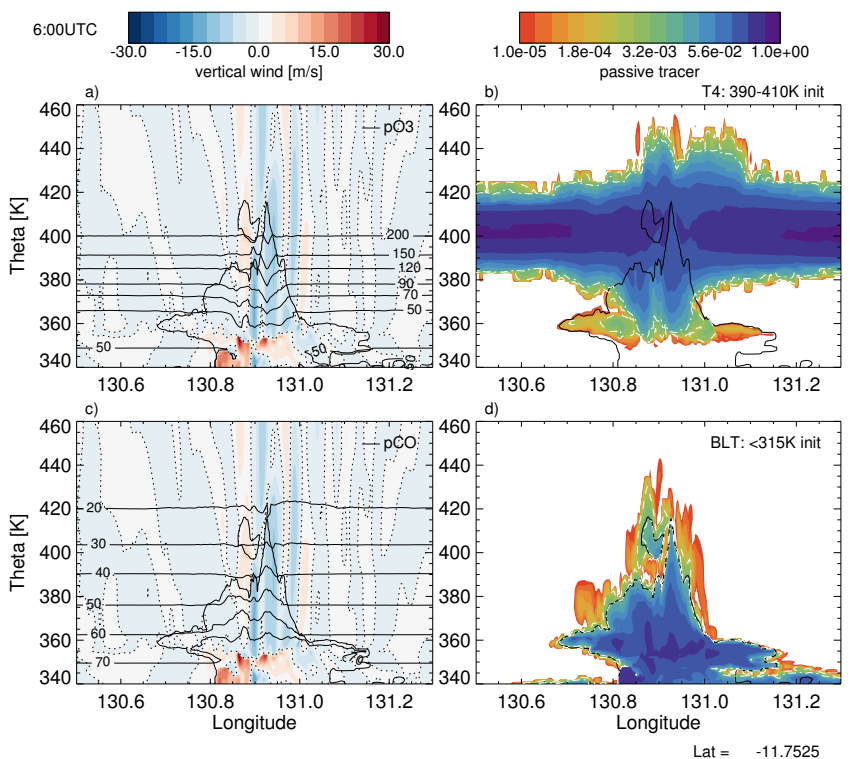

Figure 9. Same as Fig. 8 but for 06:00 UTC.

negative to positive. Thus, in the $360-380 \mathrm{~K}$ layer, these two tracers show signs of upward as well as downward mixing into this layer. Comparing the in-cloud tracers BLT and T4 reveals more influence of boundary layer air in the lower cloud parts. At about $370 \mathrm{~K}$ the in-cloud tracer profiles intersect and the influence of stratospheric air becomes more significant above this level. Convection becomes inactive at around 07:00 UTC; however, some further changes to the incloud tracer profiles may occur, presumably due to horizontal advection or other lateral in-mixing processes not related to convection.

\subsection{Turbulent kinetic energy}

In order to illustrate where the model identifies mixing, Fig. 12 shows the parameterised turbulent kinetic energy (TKE).

At 05:20 UTC there is a little mixing at the windward (eastern) part of/behind the cloud, but in Fig. 8 no mixing is clearly visible there. The two figures agree about mixing in the cloud turret. However, TKE appears only in the front part of the cloud turret. At 06:00 UTC the parameterised TKE indicates mixing in a large part of the cloud and above the cloud, though not in the front anvil. At both times TKE is highest where the isentropes show strong deviations from their relaxed state. Furthermore, the isentropes illustrate gravity wave activity, induced by the convection. The superimposed $\mathrm{u}-\mathrm{w}$ wind vectors additionally indicate the wave response. The wind reversal at 06:00 UTC at about $19 \mathrm{~km}$ and $130.94^{\circ} \mathrm{E}$ is suggestive of wave breaking. Also, at 05:20 UTC a slight reversal can be seen at about $18.5 \mathrm{~km}$ and $131.05^{\circ} \mathrm{E}$, but here it is not strong enough to cause overturning. Thus, at early times the mixing is confined to the cloud, 

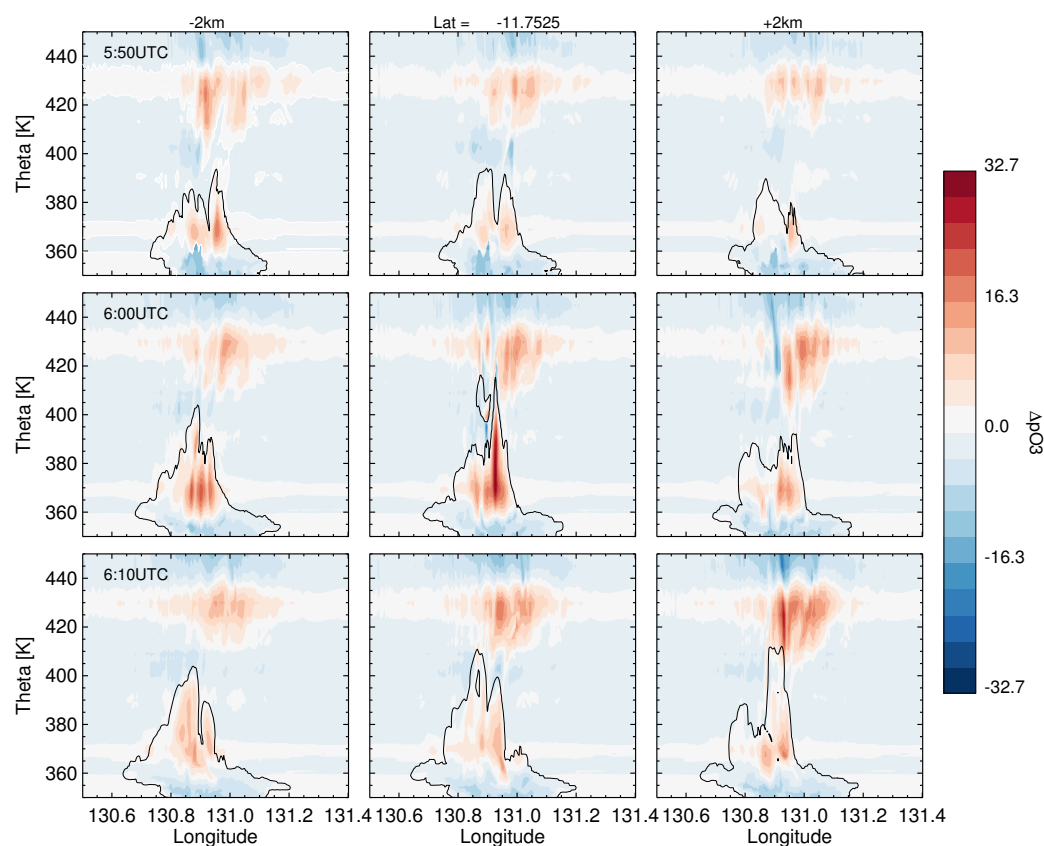

Figure 10. Cross sections of $p \mathrm{O}_{3}$ difference from the initialisation profile $\left(\Delta p \mathrm{O}_{3}\right)$. By shifting the cross section $2 \mathrm{~km}$ to the south/north (right/left) and $10 \mathrm{~min}$ prior/later (upper/lower panels), the variability of the cloud and the $\Delta p \mathrm{O}_{3}$ field becomes visible.

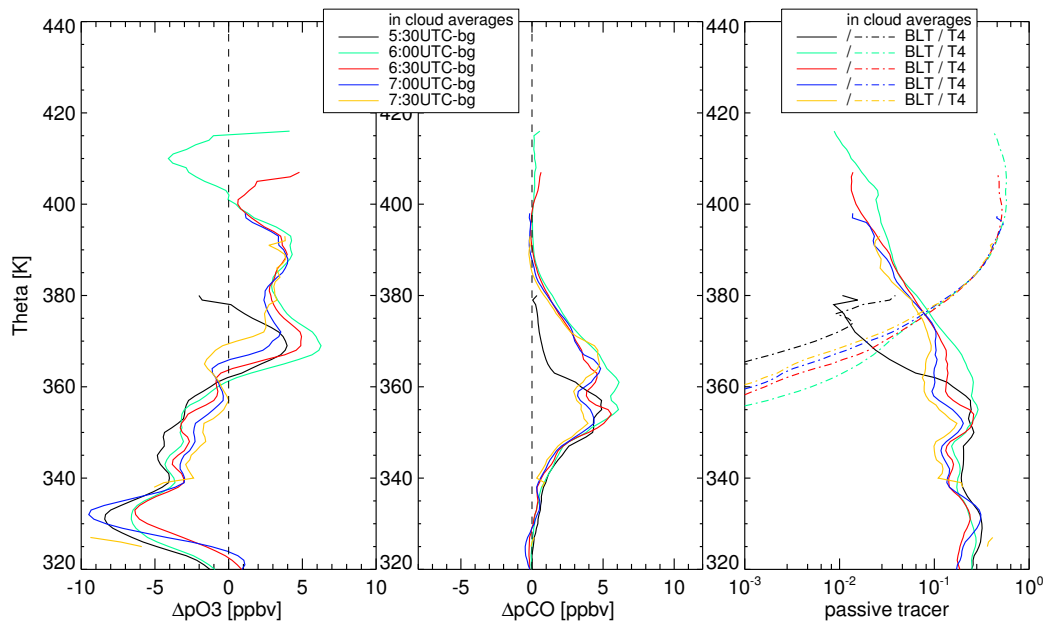

Figure 11. In-cloud average profiles of $\Delta p \mathrm{O}_{3}$ (left), $\Delta p \mathrm{CO}$ (middle), and $\mathrm{BLT}$ and T4 (right).

consistent with the localised tracer perturbations in Fig. 8. At later times, the TKE is more widespread (also outside the cloud), leading to stronger tracer perturbations.

\section{Modelled water vapour}

As the previous section indicates downward transport of stratospheric air into the upper troposphere through mixing, the question arises how it affects the water vapour fields. By bringing down dry stratospheric air, these downdrafts could lead to either direct dehydration or evaporation of cloudy air parcels, thus reducing cloud heights and cloud amount. For this reason, we look at cross sections of differences in the pre-Hector water vapour field (04:30 UTC) from Hector as well as post-Hector water vapour fields. Additionally, a further passive tracer field was initialised with the domain average water vapour profile at 04:30 UTC, hereafter called passive water vapour or $p \mathrm{H}_{2} \mathrm{O}$. Since it is passive, it does not interact, e.g. there is no phase change due to microphysics. Thus, by comparing the $p \mathrm{H}_{2} \mathrm{O}$ field to the modelled "real" water vapour field, the effects of cloud microphysics (e.g. cloud particle formation, evaporation, and sedimentation) can be studied. 

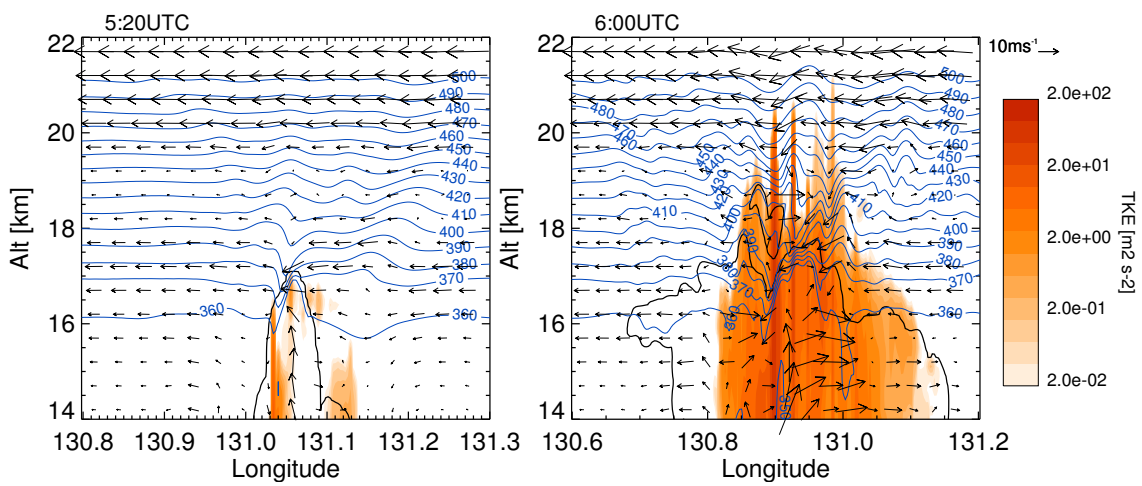

Figure 12. Vertical cross sections of parameterised TKE at 05:20 UTC (left) and 06:00 UTC (right). The thick black line denotes the $0.01 \mathrm{~g} \mathrm{~kg}^{-1}$ ice mixing ratio and the thinner blue lines depict isentropes. Also superimposed are the $u-w$ wind vectors.

The alteration of the water vapour field is shown as in the previous section for the 05:20 UTC example by means of a vertical cross section in Fig. 13a, on the left-hand side. The $0.01 \mathrm{~g} \mathrm{~kg}^{-1}$ cloud contour is depicted in solid. The cloud region next to the updraft (cf. Fig. 8) indicates some moistening compared to the pre-Hector field of up to $2.5 \mathrm{ppmv}$, while the cloud part to the east and deeper within the cloud exhibits a dehydration of up to -5 ppmv. There also is a slight dehydration above the cloud top. A hydration layer can be found outside the cloud on the bottom of the TTL. This layer is topped by a $5-10 \mathrm{~K}$ thin dehydration layer, which reaches up to $15 \mathrm{~K}$ thickness at the eastern side of the cloud and a reduction in water vapour by up to $-1.2 \mathrm{ppmv}$.

A similar picture is given by the 06:00 UTC example (Fig. 13b, left panel). The difference in the modelled water vapour fields shows a hydration in the upper downwind (western) cloud parts (up to $5 \mathrm{ppmv}$ ) and dehydration in the lower anvil and to a large part on the upwind (eastern) side of the cloud (up to $-5 \mathrm{ppmv}$ ). The stratospheric cloud parts (above $380 \mathrm{~K}$ ) are also surrounded by dehydrated air masses, reaching -1.4 ppmv. However, atop the overshoot, hydrated air spreads out in a "humidity anvil", accounting for 0.35 ppmv. The cross sections on the right of Fig. 13 show the distribution of the $p \mathrm{H}_{2} \mathrm{O}$ tracer deviation to the background profile $\left(\Delta p \mathrm{H}_{2} \mathrm{O}\right)$. Enhanced passive water vapour can be found throughout the clouds (of more than 17000 and 19000 ppmv at 05:20 and 06:00 UTC, respectively) and dehydration directly on top of the cloud. The in-cloud hydration is that massive because the tracer considers no microphysical processes. At 05:20 UTC, the cloud-top dehydration pattern reaches down to almost $370 \mathrm{~K}$ on the windward side (east), while on the western side it just reaches approximately $385 \mathrm{~K}$. Dehydration is strongest at the cloud top, reaching $-2.9 \mathrm{ppmv}$, thus stronger than in the water vapour field. Also, at 06:00 UTC, the $p \mathrm{H}_{2} \mathrm{O}$ dehydration feature on top and around the cloud top is stronger than in the water vapour field (up to -4 ppmv compared to -1.4 ppmv). Enhanced $p \mathrm{H}_{2} \mathrm{O}$ can be found in the layer around $440-460 \mathrm{~K}$, as in the water vapour field, which is in the region of the local water vapour minimum. However, in the latter, this hydration extends downward towards the cloud. At both times a $p \mathrm{H}_{2} \mathrm{O}$ hydration layer at the TTL bottom can be found, but it is somewhat thicker than in the water vapour fields and is not topped by a dehydration layer. This difference between the water vapour and $p \mathrm{H}_{2} \mathrm{O}$ fields at the TTL bottom can also be seen in the further evolution as shown in Fig. 14. Furthermore, it is found at altitudes where the model simulated a very thin cloud layer (cf. Fig. 5). Thus, the dehydration on top of the layer is a result of the microphysics.

Figure 14 shows that a layering of dehydration and hydration evolves, which, however, does not match between the water vapour and $p \mathrm{H}_{2} \mathrm{O}$ fields. This cannot solely be explained by micropysical processes, but horizontal advection also has to be taken into account, as Fig. 15 shows. For example, the 410 and $420 \mathrm{~K}$ levels show an increase in humidity from the south which cannot be seen in the $\Delta p \mathrm{H}_{2} \mathrm{O}$ field. This is an indication of horizontal advection of moisture. Still, an enhancement of moisture due to Hector can be discerned. The $\Delta p \mathrm{H}_{2} \mathrm{O}$ fields help in this regard to illustrate where Hector influenced the air masses. The 07:00 UTC examples at 390-410 K show that in the short term Hector has humidifying as well as dehydrating impacts, also visible in Fig. 14: the tower of lofted ice, which appears as a hydrating core, is surrounded by dehydrated air. In the 09:00 UTC pictures the dehydrating surrounds become less visible or even disappear. However, on all levels, enhanced moisture content can be found at places where Hector had an influence compared to the air in the background field.

Nevertheless, the ring-shaped dehydration feature at the $400 \mathrm{~K}$ level at 07:00 UTC seems to be stronger than the enclosed hydration. In a rough estimate the water vapour mixing ratio of the complete feature averages to $-0.22 \mathrm{ppmv}$, while the (unaffected) air to the north-east of this feature has an average of about -0.09 ppmv. Thus, we find a net dehydration at this level. Similarly, there are net dehydrations at 395 and $405 \mathrm{~K}$. At 09:00 UTC on the latter two levels Hec- 


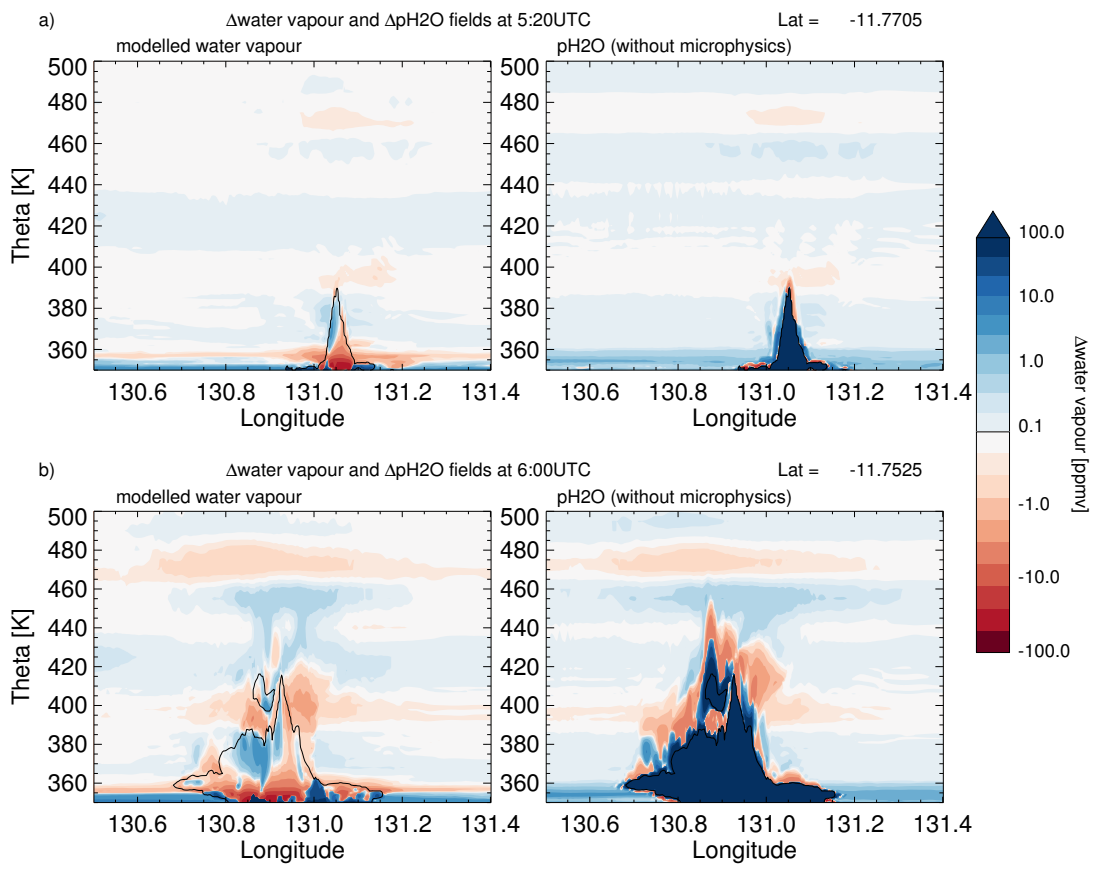

Figure 13. Cross sections of differences in modelled water vapour from the pre-Hector water vapour field (left) and $p \mathrm{H}_{2} \mathrm{O}$ from the initialisation profile (right) at 05:20 UTC (a) and 06:00 UTC (b).

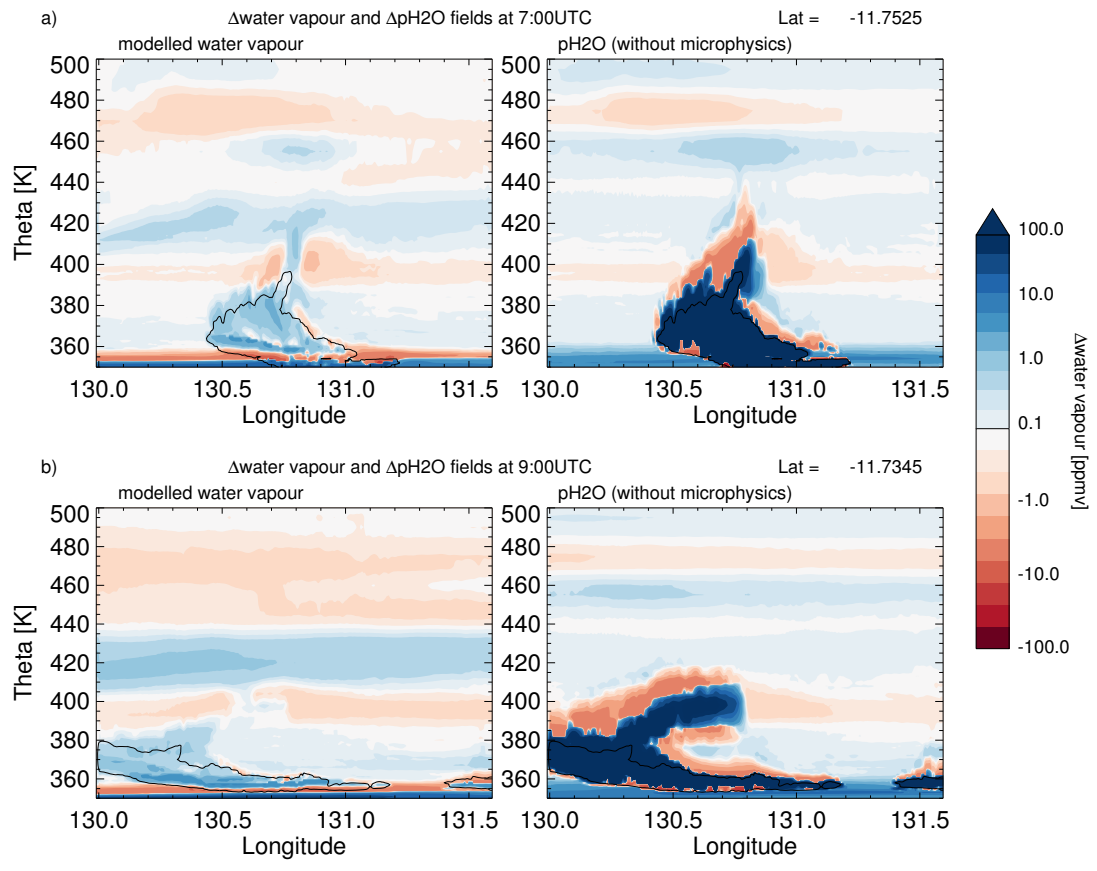

Figure 14. Same as Fig. 13 but for 07:00 UTC (a) and 09:00 UTC (b).

tor's impact changes to a slight hydration, while at $400 \mathrm{~K}$ we still see a small drying. Prior to Hector the air at these levels was subsaturated with respect to ice, while during Hector's most active phase, supersaturations can be found in small ring-shaped areas and also in the centre, certainly excited by convection-induced gravity waves. In these small regions existing ice particles may grow and thus reduce the amount of water vapour; however, since the supersaturation regions are very small, it seems more persuasive that the drying is a result of dryer air being transported by either updrafts from the 


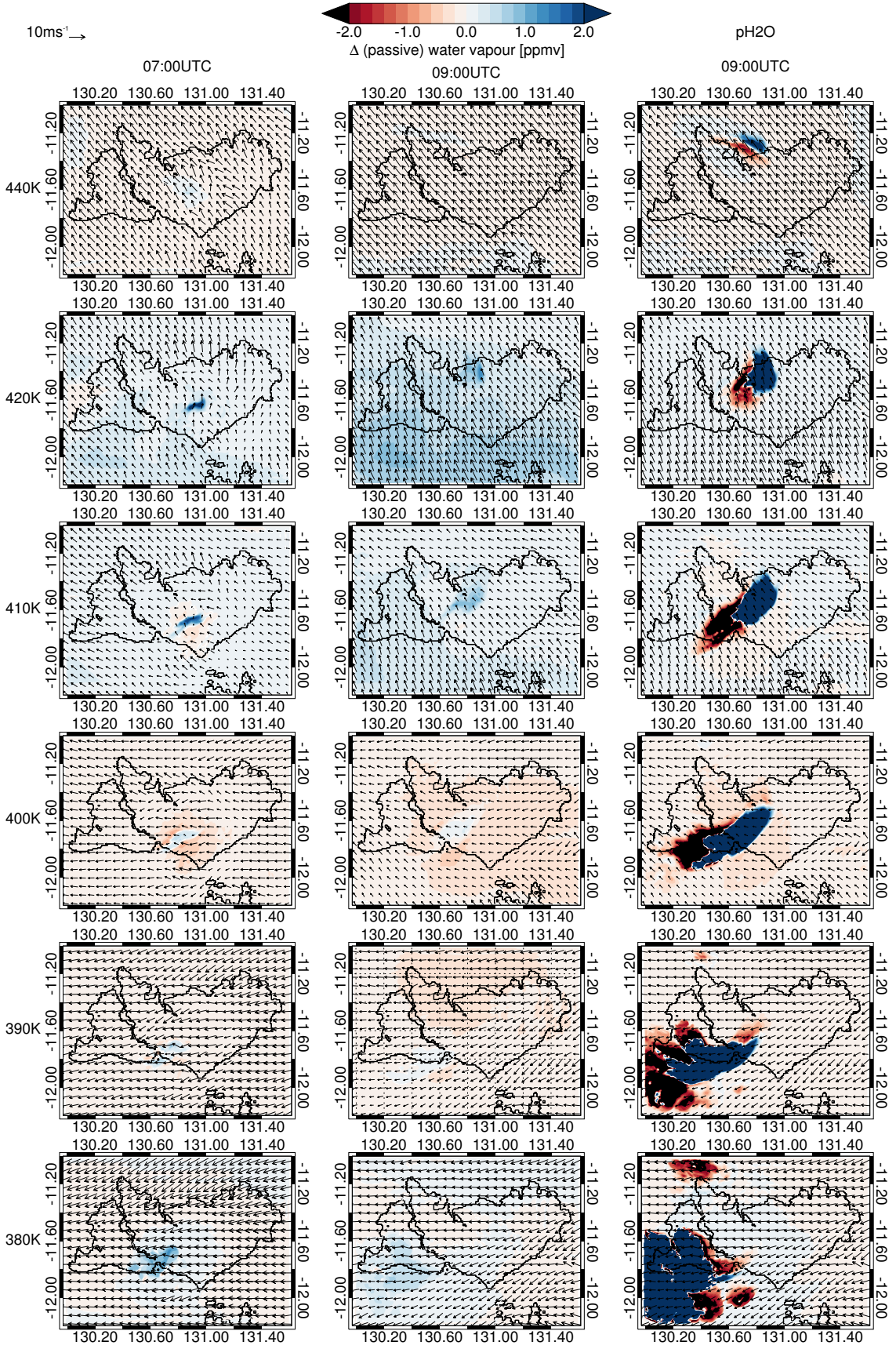

Figure 15. Change in humidity at 07:00 UTC (left column) and 09:00 UTC (middle column) on different potential temperature levels. The right column shows the change of $\mathrm{pH}_{2} \mathrm{O}$ at 09:00 UTC for comparison. Superimposed are the horizontal wind vectors on the respective level.

hygropause region (around $370 \mathrm{~K}$ ) or downdrafts from higher stratospheric levels (cf. Fig. 9). The change from dehydration at 07:00 UTC to hydration at 09:00 UTC is certainly caused by sublimating ice particles, injected by the overshoots.

The $\Delta$ water vapour and $\Delta p \mathrm{H}_{2} \mathrm{O}$ fields at 09:00 UTC in the $380,390,400$, and $440 \mathrm{~K}$ levels reveal a small general dehydration. On the $\Delta p \mathrm{H}_{2} \mathrm{O}$ fields, the drying must stem from sources other than horizontal advection or cloud micro- physics, here from a little large-scale lifting (also visible in the passive layer tracers). Thus, parts of the dehydration obvious on the $\Delta$ water vapour fields, to the extent of drying in $\Delta p \mathrm{H}_{2} \mathrm{O}$, should also be caused by the large-scale lifting. The $\Delta p \mathrm{H}_{2} \mathrm{O}$ field shows a hydrating/dehydrating dipole where Hector impacted the $p \mathrm{H}_{2} \mathrm{O}$ field. While the strong humidification is caused by the injection of $p \mathrm{H}_{2} \mathrm{O}$ from lower levels, the dehydration appears stronger than in the water vapour 
fields, since there is no sublimation possible, which provides a $p \mathrm{H}_{2} \mathrm{O}$-moisture source in the dehydrated regions.

Together, the wind and $\Delta p \mathrm{H}_{2} \mathrm{O}$ fields show the shearing of Hector in the upper levels.

\section{Discussion}

\subsection{General model representation}

There have been a number of studies pointing out the difficulty of simulating deep convective systems in general and Hector in particular. For example, Wapler et al. (2010) and Wapler and Lane (2012) highlight local difficulties in representing the timing of convection and the diurnal cycle in general. Zhu et al. (2013) point out that in their study all simulated Hectors were weaker in intensity and smaller in size than the observed thunderstorms. Problems may arise due to prescribed aerosol loads acting as condensation nuclei which do not reflect actual aerosol amounts (Connolly et al., 2013). Homeyer et al. (2014) indicate that the vertical resolution of the meteorological input fields, particularly in the UTLS, can impact the model representation of the crosstropopause transport. Also, the horizontal resolution has been shown to be an important factor in order to resolve the convective processes (Bryan et al., 2003). In this regard, Chemel et al. (2009) state that their $250 \mathrm{~m}$ resolution better resolves the convection than their $1 \mathrm{~km}$ domain, but that the characteristics are generally similar in space and time. In the simulations shown here, general features may be similar in the $333 \mathrm{~m}$ and $1 \mathrm{~km}$ domains; however, the timing is better in the higher-resolution domain and also the convective transport is stronger. In general, the simulation of the overshooting cloud tops presented here agrees reasonably well with observations (as in de Reus et al., 2009), though convection is delayed by about half an hour.

\subsection{Tracers}

The in situ measurements of ozone and $\mathrm{CO}$ on 30 November 2005 show an increase/decrease in mixing ratios in the 380-395 K layer, respectively, which suggest a downward transport of air from above. As observed overshooting cloud tops reached up to $414 \mathrm{~K}$ (de Reus et al., 2009), this alteration in trace gas mixing ratios is well within the altitude layer affected by the upper cloud parts. The tracer experiments also suggest that there is not only uplifting of boundary layer air into the upper cloud parts (overshoots and anvil), but also downward transport of stratospheric air. This downward transport, however, is weaker than would be expected from the in situ measurements of ozone and CO. The observations show an increase in ozone mixing ratios of about $50 \mathrm{ppbv}$ and a decrease in $\mathrm{CO}$ mixing ratios of about $10 \mathrm{ppbv}$, while the model suggests an increase in $\mathrm{pO}_{3}$ of about $30 \mathrm{ppbv}$ and even an increase in $p \mathrm{CO}$ and thus mixing of boundary layer and stratospheric air. Ozone could be further enhanced by pho- tochemical production (which is not simulated here) due to lightning (e.g. Bozem et al., 2014), but not by these amounts. On the other hand, Wang and Prinn (2000) show that when considering the chemical processes related to lightning in clouds, there may even be a lightning-related ozone loss. However, lightning would not affect the $\mathrm{CO}$ mixing ratios, and since there is no other source of ozone-rich and COpoor air masses, down-mixing of stratospheric air is the most likely reason for the changed tracer mixing ratios during this Hector flight. Lateral entrainment of horizontal gradients in the tracers may lead to changes in the profiles and cannot be ruled out completely here, particularly since some altitude levels are affected by horizontal advection. However, stratospheric intrusions or tropopause folds, which would lead to horizontal gradients, were not observed on this day, and the back trajectories also point towards local processes as a major contributor to the stratospheric signature.

There are a few studies that point out the possibility of overestimated upward transport in WRF, which could lead to the differences in observation and simulation. For example, Cummings et al. (2013) see an overestimation of modelled $\mathrm{CO}$ mixing ratios at anvil altitudes of a simulated Hector. Zhu et al. (2013) concluded that the imperfect simulations of convection may lead to underestimation of the exchange of trace gases between troposphere and stratosphere. The results presented here may indicate an underestimation of downward transport, an overestimation of upward transport (such that after mixing of the stratospheric and boundary layer air one sees an enhancement rather than a decrease in $\mathrm{CO}$ ), or a combination of both. Additionally, the $p \mathrm{O}_{3}$ and $p \mathrm{CO}$ tracers seem to be affected only very locally, which is not supported by the in situ measurements. It is unlikely that the Geophysica solely flew in those narrow parts (cf. the flight path in de Reus et al., 2009, Fig. 5). The measurements do not show more spread than at other altitudes, so the downward transport of air seems to be less localised than the simulations suggest. Possibly, the model does not allow enough entrainment and detrainment at the upper cloud parts. In addition, insufficient entrainment and detrainment in the free troposphere would lead to too much boundary layer air reaching the upper cloud.

\subsection{Transport and mixing}

While there are several studies showing how downdrafts carry free tropospheric air into the boundary layer (e.g. Betts et al., 2002; Sahu and Lal, 2006; Hu et al., 2010), only few report on downward mixing from the tropical stratosphere. Lu et al. (2000) showed with 2-D cloud resolving modelling that convective towers that reach the tropical tropopause have the potential to transfer ozone-rich air down into the cloud anvil. While their model reproduces observed deep convective clouds, the measurements do not include trace gases. With a 3-D cloud resolving model, Barthe et al. (2011) simulated a mesoscale convective system (MCS) in West Africa, 
also using passive tracers to study vertical transport. Their UTLS tracer, initialised at $10-20 \mathrm{~km}$ altitude, was shown to be mixed downwards. However, there was no distinction between its stratospheric and tropospheric origin, and this study is also lacking trace gas measurements. Baray et al. (1999) show ozone measurements in relation to a tropical cyclone. Their measurements suggest direct transport of air from the stratosphere to the troposphere; however, an explicit determination of this exchange in the ECMWF and National Meteorological Center (NMC) model data was not visible due to the coarseness of the model grids. Similarly, Suhre et al. (1997) report ozone-rich transients over the tropical Atlantic Ocean in the vicinity of deep convection. These have been found at altitudes between 10 and $12 \mathrm{~km}$. As possible explanations for the origin of these ozone-rich air masses, they suggest either direct downward transport or quasi-isentropic transport from the extratropical stratosphere. To our knowledge, this study is the first that directly links observations and model results showing a direct transport of stratospheric air into the tropical troposphere in relation to deep (overshooting) convection on the scale of a single convective cell.

Reasons for downward transport of high ozone mixing ratios are discussed in the literature for events in the midlatitudes. These are linked to gravity wave breaking (Lamarque et al., 1996), cut-off lows (Price and Vaughan, 1993), and to tropopause folds (Shapiro, 1980). While we find no indications for the latter two possible explanations, gravity wave activity very likely plays a role in the downward transport here, as demonstrated by Fig. 12. Here, we find gravity wave breaking which is known to cause mixing (Wang, 2003; Lane and Sharman, 2006), but there is also downward transport and mixing prior to wave breaking (e.g. at 05:20 UTC). However, the downward transport may in parts still happen as a response to the gravity waves. Lane and Sharman (2006) point out that due to the vertical displacement of just a few hundred metres, gravity waves may not cause efficient mixing. Our simulation indicates transport and mixing over larger vertical distances (cf. Figs. 6 and 7) of a few kilometres or few tens of Kelvin. Thus, the convective downdrafts and their strength are a further important factor.

As the model results show, air masses are mixed downward and have a potential for chemical processing. For example, T4 is still present several tens of Kelvin below its initialisation layer hours after the convection decayed. This is contradictory to Barthe et al. (2011), who show that their UTLS tracer was not efficiently entrained into the cloud and recovered its initial value after the MCS had passed. However, the upper layer tracers in this study are not transported efficiently into the lowest layers of the atmosphere, in agreement with Barthe et al.'s findings. In another study, Böing et al. (2014) conclude that cloud top entrainment is insignificant in deep convection and that downward transport would only reach over a few hundred metres. Figures 8, 9, and 11, however, indicate downward transport over larger distances and also that the altitude layer tracers $\mathrm{A} 2, \mathrm{~A} 3$, and $\mathrm{A} 4$ are being transported several kilometres downwards (cf. Fig. 6).

Our results show the potential for stratospheric and boundary layer air to mix in the anvil of the deep convective cloud. Depending on the location of the deep convection, polluted surface air masses may be transported into the anvil from the boundary layer. Thus, two very different air masses have the potential to mix, and with the ice clouds providing surfaces for heterogeneous reactions, this air mix would be able to further undergo rapid chemical processing. von Hobe et al. (2011) point out the possibility for chlorine activation on TTL clouds. The delivery of VSLS from the boundary layer becomes more important in this light, particularly in future climates with stronger tropical convection (Hossaini et al., 2012). Additionally, the high radiation levels in the anvil region together with the cloud ice particles can lead to locally enhanced $\mathrm{OH}$ mixing ratios (Wang and Prinn, 2000), further facilitating the chemical reactions. Subsequent slow upwelling can transport this new air mix into the stratosphere.

\subsection{Water vapour}

As other modelling and observational studies, we find a moistening effect of overshooting convection on the stratosphere (e.g. Grosvenor et al., 2007; Corti et al., 2008; de Reus et al., 2009; Chemel et al., 2009). However, this moistening does not extend throughout the upper TTL and lower stratosphere; instead, there are also some layers of dehydration. One dehydration layer can be found at the TTL bottom. Here, between 352 and $362 \mathrm{~K}$, the pre-Hector water vapour field was supersaturated with respect to ice and should thereby, following Hassim and Lane (2010), lead to dehydration. The simulated dehydration here is not present in the $\Delta p \mathrm{H}_{2} \mathrm{O}$ field, indicating that microphysical processes caused the drying, as expected. In this regard, we note that the generally accepted cloud threshold of $0.01 \mathrm{~g} \mathrm{~kg}^{-1}$ might be misleading. IWCs as small as $0.01 \mathrm{mg} \mathrm{m}^{-3}$ have been observed in overshooting convection (de Reus et al., 2009). In our figures the cloud edge (with such IWCs) would better be represented by a value of $0.1 \mathrm{mg} \mathrm{kg}^{-1}$. Under this new definition the true cloud depth is captured and thus the modelled clouds reach higher than with the previous definition. For example, the 05:40 UTC overshoot in Fig. 5 would reach almost $2 \mathrm{~km}$ higher when considering a lower cloud threshold, and the overshoot at 06:00 UTC would reach approximately $20 \mathrm{~K}$ higher (reaching $440 \mathrm{~K}$ instead of roughly $420 \mathrm{~K}$; cf. Fig. 13). Furthermore, a thin layer at the TTL bottom would be classified as cloud, corroborating that microphysical processes have led to the dehydration in this layer.

The levels above (upper TTL and stratosphere) all show $\mathrm{RH}_{\mathrm{i}}<100 \%$ in the pre-Hector profile and also in the averages at later times. Thus, ice crystals in these layers are subject to sublimation and consequently humidify air here, and no dehydration is to be expected (Hassim and Lane, 2010). Nevertheless, between 395 and $405 \mathrm{~K}$, dehydration is found 
at 07:00 UTC, which however mostly turns into hydration at 09:00 UTC. Ice has been injected into these levels by Hector, which will sublimate and humidify the air. Depending on the size of the ice particles, complete sublimation can take a few hours (cf. Fig. 7 from de Reus et al., 2009), hence the change from initial dehydration at times closer to ice particle injection to hydration (which at the $400 \mathrm{~K}$ level might still be in progress). The dehydration surrounding the overshooting cores can also be found in the $\mathrm{pH}_{2} \mathrm{O}$ fields, and therefore can be attributed to vertical motions, i.e. either updrafts from the hygropause $(370 \mathrm{~K})$ or downdrafts from higher, comparatively dry, stratospheric levels.

Even though Chemel et al. (2009) conclude that Hector has a moistening effect, one of their simulations shows a slight dehydration in the $370-380 \mathrm{~K}$ layer. This is at a somewhat lower altitude than in our simulation, but their hydration maximum is also approximately $10 \mathrm{~K}$ lower than ours.

Changes in the water vapour field are on the one hand caused by Hector, by transporting air with different humidity and by microphysical processes, but also by simultaneous horizontal advection of dryer or moister air. Since it is hard to disentangle the two, no statement about the amount of humidification or dehydration due to overshooting convection can be made here.

The question of how deep convective overshooting impacts humidity is unable to be answered simply by either hydration or dehydration. The background conditions in the 3-D humidity fields as well as time since the overshooting convection have to be considered. Previous studies have argued that water vapour could condense onto ice crystals in the overshot cloud turrets which then sediment and dehydrate the air (Danielsen, 1982; Jensen et al., 2007). Since the air in our simulation was subsaturated, no freezing could occur. However, air from around the hygropause, which was located at about $370 \mathrm{~K}$, was transported upwards (cf. passive tracers in Fig. 7). Thus, the dehydration in this layer could be a result of this upward transport and in-mixing of dryer air from around the water vapour minimum. Likewise, the downdrafts (cf. Fig. 9) may deliver comparatively dry stratospheric air to these layers. Since the stratosphere is predominantly subsaturated with respect to ice, the question arises whether the overshooting dehydration mechanisms was a misinterpretation. It might be the reason why this mechanism could not be confirmed by modelling studies even when using relatively large ice crystal aggregation efficiencies and low aerosol concentrations (Jensen et al., 2007).

\section{Conclusions}

Simulations of the 30 November 2005 Hector event were performed with the WRF-ARW model. On the innermost domain with $333 \mathrm{~m}$ horizontal spacing, reasonable realistic representation of the modelled storm system was achieved. A number of passive tracers have been introduced to study the role of transport, including transport from the stratosphere to the troposphere. Furthermore, this study presents ozone and carbon monoxide in situ measurements that indicate downward transport from the stratosphere. Increased ozone mixing ratios and decreased $\mathrm{CO}$ mixing ratios are found in the upper TTL at altitudes concurrent with convective cloud tops. In general, the simulated passive tracers show an upward transport of boundary layer air into the cloud anvil and overshooting tops and also downward transport from the stratosphere into the TTL. Enhancement in the passive ozone tracer is found above $360 \mathrm{~K}$; however, it is not sufficient to match the measurements (up to $30 \mathrm{ppbv}$ compared to $50 \mathrm{ppbv}$ ). The $p \mathrm{CO}$ tracer, in disagreement with the observations, shows an increase between roughly 340 and $390 \mathrm{~K}$. Thus, the simulations indicate either (a) an underestimation of the downward transport of stratospheric air into the troposphere, (b) an overestimation of upward transport from the boundary layer or free troposphere, consistent with insufficient entrainment, or (c) a combination of the two. Furthermore, insufficient entrainment and detrainment in the overshooting tops and anvil parts of the convective cloud, as well as in the free troposphere, in the simulation may lead to additional discrepancies between model and observation.

These results show the high potential for mixing of boundary layer air and stratospheric air in the TTL within clouds. While halogenated VSLS are transported from the boundary layer, the clouds and strong solar radiation provide a high $\mathrm{OH}$ abundance locally. This creates a high potential for gasphase and heterogeneous chemistry in the cloud anvils and overshooting tops that can lead to ozone destruction. Pommereau (2010) points out that overshooting convection is happening much more frequently than previously thought, and thus could play a major, or even dominant, role in the transport from the troposphere to the stratosphere. In turn, convective-scale downward transport from the stratosphere as shown here should be considered when looking at TTL chemistry on local and global scales. However, it is not yet well studied and our ability to model the TTL generally is challenged. To our knowledge this is the first study that combines in situ measurements and cloud resolving modelling showing the downward transport from the stratosphere into the upper troposphere in the tropics on the convective cloud scale. This is a further indication that the transport processes around the tropical tropopause are not fully understood.

In our simulations a lower cloud contour of $0.1 \mathrm{mg} \mathrm{kg}^{-1}$ better represents observed IWCs than the generally accepted $0.01 \mathrm{~g} \mathrm{~kg}^{-1}$. Thus, we would suggest using the lower threshold for defining a model cloud. The overshooting convection has been found to affect the humidity fields of the upper TTL and the lower stratosphere. Generally, we found a moistening; to what extent is hard to disentangle due to additional horizontal advection of moister or dryer air, depending on the altitude layer. Interesting to note though is the net drying found at $400 \mathrm{~K}$ where the dehydration surrounding the cloud core is stronger than the hydration in the core, even though 
this altitude layer is generally subsaturated with respect to ice. Thus, the question of whether overshooting convection leads to hydration or dehydration is not only dependent on the initial water vapour profile, but also on the altitude of the layer and time since the overshooting. Overshooting convection in a subsaturated environment can actually lead to both hydration and dehydration.

Acknowledgements. W. Frey is supported by the DFG Research Fellowship "Tropical High Altitude Clouds and their Impact on Stratospheric Humidity" (FR 3325/1-1). The work was supported by the ARC Centre of Excellence for Climate System Science (CE110001028). This research was undertaken with the assistance of resources from the National Computational Infrastructure (NCI), which is supported by the Australian Government. We greatly acknowledge the ECMWF for providing meteorological data and G. Vaughan is acknowledged for providing the ACTIVE ozonesonde data. For helpful discussion we thank M. von Hobe from the research centre in Jülich, Germany. Special thanks to the entire Geophysica crew and the local authorities in Darwin for their excellent collaboration during the campaign. The SCOUT-O3 project was funded by the European Commission (GOCE-CT2004-505390).

Edited by: P. Haynes

\section{References}

Allen, G., Vaughan, G., Bower, K. N., Williams, P. I., Crosier, J., Flynn, M., Connolly, P., Hamilton, J. F., Lee, J. D., Saxton, J. E., Watson, N. M., Gallagher, M., Coe, H., Allan, J., Choularton, T. W., and Lewis, A. C.: Aerosol and trace-gas measurements in the Darwin area during the wet season, J. Geophys. Res., 113, D06306, doi:10.1029/2007JD008706, 2008.

Aschmann, J., Sinnhuber, B.-M., Chipperfield, M. P., and Hossaini, R.: Impact of deep convection and dehydration on bromine loading in the upper troposphere and lower stratosphere, Atmos. Chem. Phys., 11, 2671-2687, doi:10.5194/acp-11-2671-2011, 2011.

Baray, J.-L., Ancellet, G., Randriambelo, T., and Baldy, S.: Tropical cyclone Marlene and stratosphere-troposphere exchange, J. Geophys. Res., 104, 13953-13970, doi:10.1029/1999JD900028, 1999.

Barth, M. C., Kim, S. W., Wang, C., Pickering, K. E., Ott, L. E., Stenchikov, G., Leriche, M., Cautenet, S., Pinty, J. P., Barthe, C., Mari, C., Helsdon, J. H., Farley, R. D., Fridlind, A. M., Ackerman, A. S., Spiridonov, V., and Telenta, B.: Cloud-scale model intercomparison of chemical constituent transport in deep convection, Atmos. Chem. Phys., 7, 4709-4731, doi:10.5194/acp-74709-2007, 2007.

Barthe, C., Mari, C., Chaboureau, J. P., Tulet, P., Roux, F., and Pinty, J. P.: Numerical study of tracers transport by a mesoscale convective system over West Africa, Ann. Geophys., 29, 731-747, doi:10.5194/angeo-29-731-2011, 2011.

Betts, A. K., Gatti, L. V., Cordova, A. M., Silva Dias, M. A. F., and Fuentes, J. D.: Transport of ozone to the surface by convective downdrafts at night, J. Geophys. Res., 107, 8046, doi:10.1029/2000JD000158, 2002.

Böing, S. J., Jonker, H. J. J., Nawara, W. A., and Siebesma, A. P.: On the Deceiving Aspects of Mixing Diagrams of Deep Cumulus Convection, J. Atmos. Sci., 71, 56-68, doi:10.1175/JAS-D-130127.1, 2014.

Bozem, H., Fischer, H., Gurk, C., Schiller, C. L., Parchatka, U., Koenigstedt, R., Stickler, A., Martinez, M., Harder, H., Kubistin, D., Williams, J., Eerdekens, G., and Lelieveld, J.: Influence of corona discharge on the ozone budget in the tropical free troposphere: a case study of deep convection during GABRIEL, Atmos. Chem. Phys., 14, 8917-8931, doi:10.5194/acp-14-89172014, 2014.

Brunner, D., Siegmund, P., May, P. T., Chappel, L., Schiller, C., Müller, R., Peter, T., Fueglistaler, S., MacKenzie, A. R., Fix, A., Schlager, H., Allen, G., Fjæraa, A. M., Streibel, M., and Harris, N. R. P.: The SCOUT-O3 Darwin Aircraft Campaign: rationale and meteorology, Atmos. Chem. Phys., 9, 93-117, doi:10.5194/acp-9-93-2009, 2009.

Bryan, G. H., Wyngaard, J. C., and Fritsch, J. M.: Resolution requirements for the simulation of deep moist convection, Mon. Weather Rev., 131, 2394-2416, doi:10.1175/15200493(2003)131<2394:RRFTSO>2.0.CO;2, 2003.

Carbone, R. E., Wilson, J. W., Keenan, T. D., and Hacker, J. M.: Tropical island convection in the absence of significant topography. Part I: Life cycle of diurnally forced convection, Mon. Weather Rev., 128, 3459-3480, doi:10.1175/15200493(2000)128<3459:TICITA>2.0.CO;2, 2000.

Chaboureau, J.-P., Cammas, J.-P., Duron, J., Mascart, P. J., Sitnikov, N. M., and Voessing, H.-J.: A numerical study of tropical crosstropopause transport by convective overshoots, Atmos. Chem. Phys., 7, 1731-1740, doi:10.5194/acp-7-1731-2007, 2007.

Chagnon, J. M. and Gray, S. L.: A comparison of stratospheretroposphere transport in convection-permitting and convection-parameterizing simulations of three mesoscale convective systems, J. Geophys. Res., 115, D24318, doi:10.1029/2010JD014421, 2010.

Chemel, C., Russo, M. R., Pyle, J. A., Sokhi, R. S., and Schiller, C.: Quantifying the Imprint of a Severe Hector Thunderstorm during ACTIVE/SCOUT-O3 onto the Water Content in the Upper Troposphere/Lower Stratosphere, Mon. Weather Rev., 137, 2493-2514, doi:10.1175/2008MWR2666.1, 2009.

Chen, F. and Dudhia, J.: Coupling an Advanced Land SurfaceHydrology Model with the Penn State - NCAR MM5 Modeling System. Part I: Model Implementation and Sensitivity, Mon. Weather Rev., 129, 569-585, doi:10.1175/15200493(2001)129<0569:CAALSH>2.0.CO;2, 2001.

Connolly, P. J., Vaughan, G., May, P. T., Chemel, C., Allen, G., Choularton, T. W., Gallagher, M. W., Bower, K. N., Crosier, J., and Dearden, C.: Can aerosols influence deep tropical convection? Aerosol indirect effects in the Hector island thunderstorm, Q. J. Roy. Meteor. Soc., 139, 2190-2208, doi:10.1002/qj.2083, 2013.

Corti, T., Luo, B. P., Fu, Q., Vomel, H., and Peter, T.: The impact of cirrus clouds on tropical troposphere-to-stratosphere transport, Atmos. Chem. Phys., 6, 2539-2547, doi:10.5194/acp-6-25392006, 2006.

Corti, T., Luo, B. P., de Reus, M., Brunner, D., Cairo, F., Mahoney, M. J., Martucci, G., Matthey, R., Mitev, V., dos Santos, 
F. H., Schiller, C., Shur, G., Sitnikov, N. M., Spelten, N., Vössing, H. J., Borrmann, S., and Peter, T.: Unprecedented evidence for deep convection hydrating the tropical stratosphere, Geophys. Res. Lett., 35, L10810, doi:10.1029/2008GL033641, 2008.

Crook, N. A.: Understanding Hector: The dynamics of island thunderstorms, Mon. Weather Rev., 129, 1550-1563, doi:10.1175/1520-0493(2001)129<1550:UHTDOI >2.0.CO;2, 2001.

Cummings, K. A., Huntemann, T. L., Pickering, K. E., Barth, M. C., Skamarock, W. C., Höller, H., Betz, H.-D., Volz-Thomas, A., and Schlager, H.: Cloud-resolving chemistry simulation of a Hector thunderstorm, Atmos. Chem. Phys., 13, 2757-2777, doi:10.5194/acp-13-2757-2013, 2013.

Danielsen, E. F.: A Dehydration Mechanism For the Stratosphere, Geophys. Res. Lett., 9, 605-608, doi:10.1029/GL009i006p00605, 1982.

Dee, D. P., Uppala, S. M., Simmons, A. J., Berrisford, P., Poli, P., Kobayashi, S., Andrae, U., Balmaseda, M. A., Balsamo, G., Bauer, P., Bechtold, P., Beljaars, A. C. M., van de Berg, L., Bidlot, J., Bormann, N., Delsol, C., Dragani, R., Fuentes, M., Geer, A. J., Haimberger, L., Healy, S. B., Hersbach, H., Hólm, E. V., Isaksen, L., Kållberg, P., Köhler, M., Matricardi, M., McNally, A. P., Monge-Sanz, B. M., Morcrette, J. J., Park, B. K., Peubey, C., de Rosnay, P., Tavolato, C., Thépaut, J. N., and Vitart, F.: The ERA-Interim reanalysis: configuration and performance of the data assimilation system, Q. J. Roy. Meteor. Soc., 137, 553-597, doi:10.1002/qj.828, 2011.

de Reus, M., Borrmann, S., Bansemer, A., Heymsfield, A. J., Weigel, R., Schiller, C., Mitev, V., Frey, W., Kunkel, D., Kürten, A., Curtius, J., Sitnikov, N. M., Ulanovsky, A., and Ravegnani, F.: Evidence for ice particles in the tropical stratosphere from in-situ measurements, Atmos. Chem. Phys., 9, 6775-6792, doi:10.5194/acp-9-6775-2009, 2009.

Farr, T. G., Rosen, P. A., Caro, E., Crippen, R., Duren, R., Hensley, S., Kobrick, M., Paller, M., Rodriguez, E., Roth, L., Seal, D., Shaffer, S., Shimada, J., Umland, J., Werner, M., Oskin, M., Burbank, D., and Alsdorf, D.: The Shuttle Radar Topography Mission, Rev. Geophys., 45, RG2004, doi:10.1029/2005RG000183, 2007

Ferrier, B. S.: A Double-Moment Multiple-Phase Four-Class Bulk Ice Scheme. Part I: Description, J. Atmos. Sci., 51, 249-280, doi:10.1175/1520-0469(1994)051<0249:ADMMPF>2.0.CO;2, 1994.

Folkins, I., Braun, C., Thompson, A. M., and Witte, J.: Tropical ozone as an indicator of deep convection, J. Geophys. Res., 107, ACH 13-1-ACH 13-10, doi:10.1029/2001JD001178, 2002.

Forster, P. M., Bodeker, G., Schofield, R., Solomon, S., and Thompson, D.: Effects of ozone cooling in the tropical lower stratosphere and upper troposphere RID F-9829-2010 RID A-88702008 RID A-4062-2010, Geophys. Res. Lett., 34, L23813, doi:10.1029/2007GL031994, 2007.

Frey, W., Borrmann, S., Fierli, F., Weigel, R., Mitev, V., Matthey, R., Ravegnani, F., Sitnikov, N. M., Ulanovsky, A., and Cairo, F.: Tropical deep convective life cycle: Cb-anvil cloud microphysics from high-altitude aircraft observations, Atmos. Chem. Phys., 14, 13223-13240, doi:10.5194/acp-14-13223-2014, 2014.

Friedl, M., McIver, D., Hodges, J., Zhang, X., Muchoney, D., Strahler, A., Woodcock, C., Gopal, S., Schneider, A., Cooper, A., Baccini, A., Gao, F., and Schaaf, C.: Global land cover mapping from MODIS: algorithms and early results, Remote Sens. Environ., 83, 287-302, doi:10.1016/S0034-4257(02)00078-0, 2002.

Fueglistaler, S., Dessler, A. E., Dunkerton, T. J., Folkins, I., Fu, Q., and Mote, P. W.: Tropical tropopause layer, Rev. Geophys., 47, RG1004, doi:10.1029/2008RG000267, 2009.

Grosvenor, D. P., Choularton, T. W., Coe, H., and Held, G.: A study of the effect of overshooting deep convection on the water content of the TTL and lower stratosphere from Cloud Resolving Model simulations, Atmos. Chem. Phys., 7, 4977-5002, doi:10.5194/acp-7-4977-2007, 2007.

Hassim, M. E. E. and Lane, T. P.: A model study on the influence of overshooting convection on TTL water vapour, Atmos. Chem. Phys., 10, 9833-9849, doi:10.5194/acp-10-9833-2010, 2010.

Hassim, M. E. E., Lane, T. P., and May, P. T.: Ground-based observations of overshooting convection during the Tropical Warm Pool-International Cloud Experiment, J. Geophys. Res. Atmos., 119, 880-905, doi:10.1002/2013JD020673, 2014.

Hegglin, M. I., Brunner, D., Wernli, H., Schwierz, C., Martius, O., Hoor, P., Fischer, H., Parchatka, U., Spelten, N., Schiller, C., Krebsbach, M., Weers, U., Staehelin, J., and Peter, T.: Tracing troposphere-to-stratosphere transport above a mid-latitude deep convective system, Atmos. Chem. Phys., 4, 741-756, doi:10.5194/acp-4-741-2004, 2004.

Heymsfield, G. M., Tian, L., Heymsfield, A. J., Li, L. H., and Guimond, S.: Characteristics of Deep Tropical and Subtropical Convection from Nadir-Viewing High-Altitude Airborne Doppler Radar, J. Atmos. Sci., 67, 285-308, doi:10.1175/2009JAS3132.1, 2010.

Holton, J. R., Haynes, P. H., McIntyre, M. E., Douglass, A. R., Rood, R. B., and Pfister, L.: Stratosphere-troposphere exchange, Rev. Geophys., 33, 403-439, doi:10.1029/95RG02097, 1995.

Homeyer, C. R., Pan, L. L., and Barth, M. C.: Transport from convective overshooting of the extratropical tropopause and the role of large-scale lower stratosphere stability, J. Geophys. Res.Atmos., 119, 2220-2240, doi:10.1002/2013JD020931, 2014.

Hossaini, R., Chipperfield, M. P., Dhomse, S., Ordóñez, C., Saiz-Lopez, A., Abraham, N. L., Archibald, A., Braesicke, P., Telford, P., Warwick, N., Yang, X., and Pyle, J.: Modelling future changes to the stratospheric source gas injection of biogenic bromocarbons, Geophys. Res. Lett., 39, L20813, doi:10.1029/2012GL053401, 2012.

Hoyle, C. R., Marécal, V., Russo, M. R., Allen, G., Arteta, J., Chemel, C., Chipperfield, M. P., D’Amato, F., Dessens, O., Feng, W., Hamilton, J. F., Harris, N. R. P., Hosking, J. S., Lewis, A. C., Morgenstern, O., Peter, T., Pyle, J. A., Reddmann, T., Richards, N. A. D., Telford, P. J., Tian, W., Viciani, S., Volz-Thomas, A., Wild, O., Yang, X., and Zeng, G.: Representation of tropical deep convection in atmospheric models - Part 2: Tracer transport, Atmos. Chem. Phys., 11, 8103-8131, doi:10.5194/acp-118103-2011, 2011.

Hu, X. M., Fuentes, J. D., and Zhang, F. Q.: Downward transport and modification of tropospheric ozone through moist convection, J. Atmos. Chem., 65, 13-35, doi:10.1007/s10874-0109179-5, 2010.

Huntrieser, H., Schlager, H., Roiger, A., Lichtenstern, M., Schumann, U., Kurz, C., Brunner, D., Schwierz, C., Richter, A., and Stohl, A.: Lightning-produced $\mathrm{NO}_{\mathrm{x}}$ over Brazil during TROCCINOX: airborne measurements in tropical and subtropical thunderstorms and the importance of mesoscale convective systems, 
Atmos. Chem. Phys., 7, 2987-3013, doi:10.5194/acp-7-29872007, 2007.

Iacono, M. J., Delamere, J. S., Mlawer, E. J., Shephard, M. W., Clough, S. A., and Collins, W. D.: Radiative forcing by longlived greenhouse gases: Calculations with the AER radiative transfer models, J. Geophys. Res.-Atmos., 113, D13103, doi:10.1029/2008JD009944, 2008.

Janjic, Z. I.: The Step-mountain Eta Coordinate Model - Further Developments of the Convection, Viscous Sublayer, and Turbulence Closure Schemes, Mon. Weather Rev., 122, 927-945, doi:10.1175/1520-0493(1994)122<0927:TSMECM>2.0.CO;2, 1994.

Jensen, E. J., Ackerman, A. S., and Smith, J. A.: Can overshooting convection dehydrate the tropical tropopause layer?, J. Geophys. Res.-Atmos., 112, D11209, doi:10.1029/2006JD007943, 2007.

Keenan, T. D., Ferrier, B., and Simpson, J.: Development and Structure of A Maritime Continent Thunderstorm, Meteorol. Atmos. Phys., 53, 185-222, doi:10.1007/BF01029612, 1994.

Lamarque, J. F., Langford, A. O., and Proffitt, M. H.: Crosstropopause mixing of ozone through gravity wave breaking: Observation and modeling, J. Geophys. Res.-Atmos., 101, 2296922976, doi:10.1029/96JD02442, 1996.

Lane, T. P. and Sharman, R. D.: Gravity wave breaking, secondary wave generation, and mixing above deep convection in a threedimensional cloud model, Geophys. Res. Lett., 33, L23813, doi:10.1029/2006GL027988, 2006.

Law, K. S. and Sturges, W. T.: WMO (World Meteorological Organization) Scientific Assessment of Ozone Depletion: 2006, Global Ozone Research and Monitoring Project, Chapter 2. Halogenated Very Short-Lived Substances, 2.1-2.57, Report No. 50, World Meteorological Organization, Geneva, 2007.

Lim, K. S. S. and Hong, S. Y.: Development of an Effective Double-Moment Cloud Microphysics Scheme with Prognostic Cloud Condensation Nuclei (CCN) for Weather and Climate Models, Mon. Weather Rev., 138, 1587-1612, doi:10.1175/2009MWR2968.1, 2010.

Lu, R., Lin, C. C., Turco, R., and Arakawa, A.: Cumulus transport of chemical tracers 1. Cloud-resolving model simulations, J. Geophys. Res.-Atmos., 105, 10001-10021, doi:10.1029/2000JD900009, 2000.

Mansell, E. R., Ziegler, C. L., and Bruning, E. C.: Simulated Electrification of a Small Thunderstorm with TwoMoment Bulk Microphysics, J. Atmos. Sci., 67, 171-194, doi:10.1175/2009JAS2965.1, 2010.

Morrison, H., Thompson, G., and Tatarskii, V.: Impact of Cloud Microphysics on the Development of Trailing Stratiform Precipitation in a Simulated Squall Line: Comparison of One- and Two-Moment Schemes, Mon. Weather Rev., 137, 991-1007, doi:10.1175/2008MWR2556.1, 2009.

Mullendore, G. L., Durran, D. R., and Holton, J. R.: Crosstropopause tracer transport in midlatitude convection, J. Geophys. Res.-Atmos., 110, D06,113, doi:10.1029/2004JD005059, 2005.

Pan, L. L., Homeyer, C. R., Honomichl, S., Ridley, B. A., Weisman, M., Barth, M. C., Hair, J. W., Fenn, M. A., Butler, C., Diskin, G. S., Crawford, J. H., Ryerson, T. B., Pollack, I., Peischl, J., and Huntrieser, H.: Thunderstorms enhance tropospheric ozone by wrapping and shedding stratospheric air, Geophys. Res. Lett., 41, GL061921, doi:10.1002/2014GL061921, 2014.
Pergaud, J., Masson, V., Malardel, S., and Couvreux, F.: A Parameterization of Dry Thermals and Shallow Cumuli for Mesoscale Numerical Weather Prediction, Bound.-Lay. Meteorol., 132, 83106, doi:10.1007/s10546-009-9388-0, 2009.

Pommereau, J. P.: Troposphere-to-stratosphere transport in the tropics, CR Geosci., 342, 331-338, doi:10.1016/j.crte.2009.10.015, 2010.

Poulida, O., Dickerson, R. R., and Heymsfield, A.: Stratospheretroposphere exchange in a midlatitude mesoscale convective complex, J. Geophys. Res.-Atmos., 101, 6823-6836, doi:10.1029/95JD03523, 1996.

Price, J. D. and Vaughan, G.: The Potential For Stratosphere Troposphere Exchange In Cut-off-low Systems, Q. J. Roy. Meteor. Soc., 119, 343-365, doi:10.1002/qj.49711951007, 1993.

Randel, W. J. and Jensen, E. J.: Physical processes in the tropical tropopause layer and their roles in a changing climate, Nat. Geosci., 6, 169-176, doi:10.1038/ngeo1733, 2013.

Romps, D. M. and Kuang, Z. M.: Do Undiluted Convective Plumes Exist in the Upper Tropical Troposphere?, J. Atmos. Sci., 67, 468-484, doi:10.1175/2009JAS3184.1, 2010.

Sahu, L. K. and Lal, S.: Changes in surface ozone levels due to convective downdrafts over the Bay of Bengal, Geophys. Res. Lett., 33, L10807, doi:10.1029/2006GL025994, 2006.

Shapiro, M. A.: Turbulent Mixing within Tropopause Folds as a Mechanism for the Exchange of Chemical Constituents between the Stratosphere and Troposphere, J. Atmos. Sci., 37, 994-1004, doi:10.1175/1520-0469(1980)037<0994:TMWTFA>2.0.CO;2, 1980 .

Solomon, S., Rosenlof, K. H., Portmann, R. W., Daniel, J. S., Davis, S. M., Sanford, T. J., and Plattner, G.-K.: Contributions of Stratospheric Water Vapor to Decadal Changes in the Rate of Global Warming, Science, 327, 1219-1223, doi:10.1126/science.1182488, 2010.

Stenchikov, G., Dickerson, R., Pickering, K., Ellis, W., Doddridge, B., Kondragunta, S., Poulida, O., Scala, J., and Tao, W. K.: Stratosphere-troposphere exchange in a midlatitude mesoscale convective complex .2. Numerical simulations, J. Geophys. Res.Atmos., 101, 6837-6851, doi:10.1029/95JD02468, 1996.

Stohl, A., Wernli, H., James, P., Bourqui, M., Forster, C., Liniger, M. A., Seibert, P., and Sprenger, M.: A New Perspective of Stratosphere-Troposphere Exchange, Bull. Amer. Meteor. Soc., 84, 1565-1573, doi:10.1175/BAMS-84-11-1565, 2003.

Suhre, K., Cammas, J. P., Nedelec, P., Rosset, R., Marenco, A., and Smit, H. G. J.: Ozone-rich transients in the upper equatorial Atlantic troposphere, Nature, 388, 661-663, doi:10.1038/41749, 1997.

Sukoriansky, S., Galperin, B., and Staroselsky, I.: A quasinormal scale elimination model of turbulent flows with stable stratification, Phys. Fluids, 17, 085107, doi:10.1063/1.2009010, 2005.

Tang, Q., Prather, M. J., and Hsu, J.: Stratosphere-troposphere exchange ozone flux related to deep convection, Geophys. Res. Lett., 38, L03806, doi:10.1029/2010GL046039, 2011.

Thompson, A., Tao, W., Pickering, K., Scala, J., and Simpson, J.: Tropical deep convection and ozone formation, Bull. Amer. Meteor. Soc., 78, 1043-1054, doi:10.1175/15200477(1997)078<1043:TDCAOF>2.0.CO;2, 1997.

Thompson, G., Field, P. R., Rasmussen, R. M., and Hall, W. D.: Explicit Forecasts of Winter Precipitation Using an Improved Bulk Microphysics Scheme. Part II: Implementation of a New 
Snow Parameterization, Mon. Weather Rev., 136, 5095-5115, doi:10.1175/2008MWR2387.1, 2008.

Ulanovsky, A. E., Yushkov, V. A., Sitnikov, N. M., and Ravegnani, F.: The FOZAN-II fast-response chemiluminescent airborne ozone analyzer, Instrum. Exp. Tech., 44, 249-256, doi:10.1023/A:1017535608026, 2001.

Viciani, S., D’Amato, F., Mazzinghi, P., Castagnoli, F., Toci, G., and Werle, P.: A cryogenically operated laser diode spectrometer for airborne measurement of stratospheric trace gases, Appl. Phys. B-Lasers O., 90, 581-592, doi:10.1007/s00340-007-28852, 2008.

von Hobe, M., Grooß, J.-U., Günther, G., Konopka, P., Gensch, I., Krämer, M., Spelten, N., Afchine, A., Schiller, C., Ulanovsky, A., Sitnikov, N., Shur, G., Yushkov, V., Ravegnani, F., Cairo, F., Roiger, A., Voigt, C., Schlager, H., Weigel, R., Frey, W., Borrmann, S., Müller, R., and Stroh, F.: Evidence for heterogeneous chlorine activation in the tropical UTLS, Atmos. Chem. Phys., 11, 241-256, doi:10.5194/acp-11-241-2011, 2011.

Wang, C. and Prinn, R. G.: On the roles of deep convective clouds in tropospheric chemistry, J. Geophys. Res., 105, 22269-22297, doi:10.1029/2000JD900263, 2000.

Wang, P. K.: Moisture plumes above thunderstorm anvils and their contributions to cross-tropopause transport of water vapor in midlatitudes, J. Geophys. Res.-Atmos., 108, 4194, doi:10.1029/2002JD002581, 2003.
Wapler, K. and Lane, T.: A case of offshore convective initiation by interacting land breezes near Darwin, Australia, Meteorol. Atmos. Phys., 115, 123-137, doi:10.1007/s00703-011-0180-6, 2012.

Wapler, K., Lane, T. P., May, P. T., Jakob, C., Manton, M. J., and Siems, S. T.: Cloud-System-Resolving Model Simulations of Tropical Cloud Systems Observed during the Tropical Warm Pool-International Cloud Experiment, Mon. Weather Rev., 138, 55-73, doi:10.1175/2009MWR2993.1, 2010.

Wernli, B. H. and Davies, H. C.: A lagrangian-based analysis of extratropical cyclones. I: The method and some applications, Q. J. Roy. Meteor. Soc., 123, 467-489, doi:10.1002/qj.49712353811, 1997.

Yushkov, V., Oulanovsky, A., Lechenuk, N., Roudakov, I., Arshinov, K., Tikhonov, F., Stefanutti, L., Ravegnani, F., Bonafe, U., and Georgiadis, T.: A Chemiluminescent Analyzer for Stratospheric Measurements of the Ozone Concentration (FOZAN), J. Atmos. Ocean. Tech., 16, 1345-1350, doi:10.1175/15200426(1999)016<1345:ACAFSM>2.0.CO;2, 1999.

Zhu, M., Connolly, P., Vaughan, G., Choularton, T., and May, P. T.: Numerical simulation of tropical island thunderstorms (Hectors) during the ACTIVE campaign, Meteorol. Appl., 20, 357-370, doi:10.1002/met.1295, 2013. 